NBER WORKING PAPER SERIES

\title{
EMPLOYER MATCHING AND 401(K) SAVING: EVIDENCE FROM THE HEALTH AND RETIREMENT STUDY
}

\author{
Gary V. Engelhardt \\ Anil Kumar \\ Working Paper 12447 \\ http://www.nber.org/papers/w12447 \\ NATIONAL BUREAU OF ECONOMIC RESEARCH \\ 1050 Massachusetts Avenue \\ Cambridge, MA 02138 \\ August 2006
}

\begin{abstract}
All research with the restricted-access data from the Health and Retirement Study was performed under agreement in the Center for Policy Research at Syracuse University and the Federal Reserve Bank of Dallas. We thank Dan Black, David Card, Courtney Coile, Chris Cunningham, Bill Gale, Erik Hurst, Annamaria Lusardi, Brigitte Madrian, Costas Meghir, John Moran, Susann Rohwedder, Clemens Sialm, and seminar participants at Syracuse University, University of Chicago, University of Missouri, University of Virginia, Dutch Central Bank, Econometric Society World Congress, Federal Reserve Bank of Dallas, and the NBER Transatlantic Public Economics Seminar for helpful discussions and comments. We are especially grateful to Bob Peticolas and Helena Stolyarova for their efforts in helping us understand the HRS employer-provided pension plan data. The research reported herein was supported (in part) by a grant from the TIAA-CREF Institute and (in part) by the Center for Retirement Research at Boston College pursuant to a grant from the U.S. Social Security Administration funded as part of the Retirement Research Consortium. Various portions of the underlying data construction were funded by the Center for Policy Research at Syracuse University, the Economics Program, National Science Foundation, under Grant No. SES-0078845, National Institute on Aging, under Grant No. 1 R03 AG19895-01, and the U.S. Department of Labor. The opinions and conclusions are solely those of the authors and should not be construed as representing the opinions or policy of the Social Security Administration, Federal Reserve Bank of Dallas, Federal Reserve System, any agency of the Federal Government, Center for Retirement Research at Boston College, TIAA-CREF, United States Department of Labor, National Science Foundation, National Institute on Aging, or Syracuse University. All errors are our own. The views expressed herein are those of the author(s) and do not necessarily reflect the views of the National Bureau of Economic Research.
\end{abstract}

(O2006 by Gary V. Engelhardt and Anil Kumar. All rights reserved. Short sections of text, not to exceed two paragraphs, may be quoted without explicit permission provided that full credit, including $\odot$ notice, is given to the source. 
Employer Matching and 401(k) Saving: Evidence From the Health and Retirement Study

Gary V. Engelhardt and Anil Kumar

NBER Working Paper No. 12447

August 2006

JEL No. E21, H24, J32

\begin{abstract}
Employer matching of employee 401(k) contributions can provide a powerful incentive to save for retirement and is a key component in pension-plan design in the United States. Using detailed administrative contribution, earnings, and pension-plan data from the Health and Retirement Study, this analysis formulates a life-cycle-consistent econometric specification of 401(k) saving and estimates the determinants of saving accounting for non-linearities in the household budget set induced by matching. The participation estimates indicate that an increase in the match rate by 25 cents per dollar of employee contribution raises $401(\mathrm{k})$ participation by 3.75 to 6 percentage points, and the estimated elasticity of participation with respect to matching ranges from 0.02-0.07. The parametric and semi-parametric estimates for saving indicate that an increase in the match rate by 25 cents per dollar of employee contribution raises $401(\mathrm{k})$ saving by $\$ 400-\$ 700$ (in 1991 dollars). The estimated elasticity of $401(\mathrm{k})$ saving to matching is also small and ranges from 0.09-0.12 overall, with just under half of this effect on the intensive margin. Overall, the analysis reveals that matching is a rather poor policy instrument with which to raise retirement saving.
\end{abstract}

Gary V. Engelhardt

Center for Policy Research

423 Eggers Hall

Syracuse University

Syracuse, NY 13244-1020

and NBER

gvengelh@maxwell.syr.edu 


\section{Introduction}

As 401(k)s have come to dominate the private pension landscape in the United States, researchers and policy makers have given increased attention to the impact of plan characteristics on retirement-saving decisions. ${ }^{1}$ One important characteristic is whether and to what extent the employer matches employee contributions. A typical match might be 50 cents for each dollar of contribution, up to a maximum percentage of pay, say, 6 percent. Although much of the discussion by the popular press and policy makers presumes employer matching raises saving, there is actually strikingly little consensus among researchers. Some studies have found that increases in the match rate raise $401(\mathrm{k})$ saving (Papke and Poterba, 1995; Clark and Schieber, 1998; VanDerhei and Copeland, 2001; and Choi, Laibson, Madrian, and Metrick, 2002). Others have found that it is not the match rate per se that matters, but whether the firm offers a match at all (Even and Macpherson, 1996; Bassett, Fleming, and Rodrigues, 1998; Papke, 1995; Kusko, Poterba, and Wilcox, 1998). That is, providing a match raises 401(k) saving, but an increase in the level of the match rate (conditional on providing a match) does not. Finally, still other studies (Employee Benefit Research Institute, 1994; Andrews, 1992; Munnell, Sunden, and Taylor, 1998; and GAO, 1997) have suggested that, conditional on being eligible for a match, an increase in the match rate lowers $401(\mathrm{k})$ contributions, which, when interpreted in the context of a simple two-period model of saving, suggests that the income effect dominates the substitution effect from the higher rate of return matching

\footnotetext{
1 This includes work on automatic enrollment (Madrian and Shea, 2001; Choi, Laibson, Madrian, and Metrick, 2002, 2004), investment in company stock (Poterba, 2003; Brown, Liang, and Weisbenner, 2004; Mitchell and Utkus, 2002), portfolio choice and trading in 401(k) plans (Benartzi and Thaler, 2001; Agnew, Balduzzi, and Sunden, 2003).
} 
provides. ${ }^{2}$ Overall, this ambiguity has emerged as an important empirical puzzle in the literature on saving behavior (Bernheim, 2003).

A central shortcoming in this literature has been the failure to exploit the fact that employer matching, based either on multiple-match-rate schedules or caps on the generosity of the match, results in a non-linear household budget set. As has been long recognized in the study of taxation on labor supply, reduced-form estimates of behavioral elasticities are biased and inconsistent unless the non-linearity is accounted for explicitly (Hausman, 1985; Moffitt, 1990; Blundell and MaCurdy, 1999). Indeed, the presence of budget-set kinks may reconcile some of the findings of previous studies: for example, the provision of a match may raise $401(\mathrm{k})$ saving if the substitution effect dominates, but variation in match rates may not matter if employees are bunched at kinks.

Unlike previous studies, this paper includes a detailed theoretical framework that models the budget set defined by employer matching and federal tax treatment as twice continuously differentiable and then uses the first-order conditions from the consumer's optimization to derive a life-cycle-consistent econometric specification for 401(k) participation. As an alternative to the maximum-likelihood piecewise-linear-budget-set estimation summarized in Hausman (1985) - and the recent, related non-parametric extensions by Blomquist and Newey (2002)—and the maximum likelihood differentiable-budget-constraint methodology of MaCurdy, Green, and Paarsch (1990), this paper employs instrumental-variable techniques that linearize the budget set at the observed outcome to calculate the price and virtual-income terms and then instruments to correct for endogeneity, which also has a long history, but a recent example of which is

\footnotetext{
2 Throughout the paper, "401(k) saving" and "401(k) contributions" are used synonymously as per period flows. In a multi-period model, this would suggest the income effect dominates the substitution and wealth effects (Summers, 1981).
} 
Ziliak and Kniesner (1999). To calculate budget-set slopes and virtual income in a neighborhood around kink points, kernel regression is used to smooth the budget set nonparametrically. We also estimate a censored regression model of 401(k) saving to decompose the overall $401(\mathrm{k})$ saving response between the extensive and the intensive margin, where the instrumental-variable Tobit estimator of Newey $(1986,1987 \mathrm{~b})$ and an instrumental-variable symmetrically censored least squares (SCLS) estimator based on Powell (1986) and Newey (1986) are used.

Empirically, the paper makes four additional contributions. First, to circumvent difficulties with measurement error in 401(k) contributions and matching incentives that have plagued previous studies, administrative data from three sources are used: contributions from W-2 earnings records provided by the Social Security Administration (SSA) and Internal Revenue Service (IRS); detailed matching formulas from pension Summary Plan Descriptions (SPD) provided by the employers of Health and Retirement Study (HRS) respondents; and, a combination of Social-Security-covered-earnings histories for 1951-1991 and W-2 earnings for 1980-1991, pension SPDs, and pensionbenefit calculators to construct public and private pension entitlements and accruals. The sample consists of 1,042 individuals in 1991 eligible for 401(k) plans in the HRS. Second, the analysis includes a calculation of the dollar amount of unused employer matching contributions due to workers' failure to contribute at least until the point at which the employer match is exhausted. Most of this occurs because of nonparticipation. For non-participants, the unclaimed employer match represented 3.7 percent of pay. However, even participants left "money on the table" equal to 1 percent of pay in unclaimed employer match. Based on measures of liquidity constraints used by 
others in the literature, reduced-form evidence is not inconsistent with the presence of liquidity constraints as a potential explanation for this phenomenon. Third, unlike previous pension studies that have used the employer-provided SPDs in the HRS, which are available only for a non-random sub-sample of HRS respondents, the estimation uses methods laid out in Vella (1992) and Das, Newey, and Vella (2003) to correct for potential sample selection using a set of plausible exclusion restrictions derived from Internal Revenue Service (IRS) Form 5500 administrative pension-plan filings. The exclusions have substantial predictive power for determining who is in the analysis sample. There is statistically significant evidence of selection, but the economic impact of the selection on the estimates is mixed: the bias is small in the censored regression specifications of saving, but larger in the discrete choice participation specifications. Finally, there is substantial evidence of the bunching of $401(\mathrm{k})$ contributions around budget-set kink points induced by employer matching: about 25 percent of match-eligible individuals are bunched at the kink.

The estimates from the life-cycle-consistent discrete choice regression specifications for participation indicate that the estimated marginal effect of an increase in the employer match rate by 25 cents per dollar of employee contribution raises $401(\mathrm{k})$ participation by 3.75 to 6 percentage points. When the estimates are expressed in terms of elasticities, the results suggest that the impact of the match rate on 401(k) participation is quite inelastic: the estimated elasticity of $401(\mathrm{k})$ participation with respect to the match rate ranges from 0.02-0.07. In addition, the parametric and semi-parametric estimates from the two-limit censored regression specifications indicate that the estimated marginal effect of an increase in the employer match rate by 25 cents per dollar of employee 
contribution raises $401(\mathrm{k})$ contributions by $\$ 400-\$ 700$ dollars (in constant calendar year 1991 dollars). Comparing the Tobit and SCLS estimates using the Hausman-type test in Newey (1987a), the validity of the Tobit model cannot be rejected. When the Tobit estimates are expressed in terms of elasticities, the results suggest that the impact of the match rate on $401(\mathrm{k})$ saving is quite inelastic: the estimated elasticity of $401(\mathrm{k})$ saving with respect to the match rate ranges from $0.09-0.12$ overall, with just under one half of this effect on the intensive (contributions conditional on participation) margin.

Overall, because of this very inelastic response on both the intensive and the extensive margins, the analysis reveals that for employers and policy makers interested in promoting retirement saving by older workers through greater $401(\mathrm{k})$ participation and saving, matching is a rather poor policy instrument. Roughly speaking, the estimated marginal effects in this paper suggest that an increase in the employer match rate of $\$ 1$ per $\$ 1$ of employee contribution would be needed to achieve the same increase in participation as the implementation of automatic enrollment, based on the estimates in Madrian and Shea (2001) and Choi, Laibson, Madrian, and Metrick $(2002,2004)$. The analysis also suggests that government matching of voluntary contributions to any type of Social Security personal account would be relatively ineffective in promoting personalaccount contributions (Engelhardt and Kumar, 2005).

The paper is organized as follows. Sections II and III lay out the theoretical model and first-order conditions that directly motivates the empirical analysis. Section IV lays out the econometric framework and construction of the key variables. Sections V and VI describe the data. Section VII describes the empirical analysis of the relationship between matching and measures of liquidity constraints. For purposes of comparison 
with our more structural approach, Section VIII presents estimation results for ad hoc reduced-form specification similar to those in the previous literature. Section IX discusses the identification of the structural model, and section X presents the estimation results. There is a brief conclusion.

\section{Theoretical Framework}

Previous studies have had two important shortcomings. First, they have not couched their analyses in formal models of intertemporal choice, even though saving involves the substitution of resources across time. This means that previous estimates cannot be interpreted as estimates of life-cycle-consistent determinants of 401(k) saving necessarily, because the empirical specifications may not have been consistent with underlying utility maximization. So, while the existing literature has provided quite informative descriptive analyses, it has said little about how 401(k) saving may respond to prospective changes in employer matching or what the optimal match rate should be to achieve a saving target. Second, with the exception of Choi, Laibson, Madrian, and Metrick (2002), Mitchell, Utkus, and Yang (2005), and VanDerhei and Copeland (2001), previous studies have failed to exploit the fact that multiple-match-rate schedules and caps on matching induce kinks in the budget set.

By specifying a detailed theoretical framework, this paper represents a stark departure from the previous literature. In an effort to shorten the exposition, the model is presented in full in Appendix A and briefly summarized here. It has nine key features:

1) Intratemporal direct utility, $U(C, l ; \mathbf{z})$, is derived from leisure, $l$, with an associated price, $p^{l}$, consumption of a composite good, $C$, with an associated price, $p^{c}$, and a vector of demographics, $\mathbf{z}$, and is intratemporally weakly separable and intertemporally additively separable. 
2) The consumer faces a per period probability of survival of $\rho$, with period $T$ being the known maximum length of life, and with probability $1-\rho$, the consumer dies and receives the terminal payoff $\Phi\left(W^{T}\right)$, the utility of bequests, which is a function of total wealth, $W^{T}$.

3) The lifetime is composed of two parts: from period $\mathrm{N}$ to $\mathrm{T}$, the consumer is retired and no hours of labor are supplied to the market, so leisure equals the time endowment, and from period 0 to $\mathrm{N}-1$, the consumer works; the timing of retirement in period $\mathrm{N}$ is endogenous.

4) Total wealth is accumulated in seven forms when working: IRAs, 401(k)s, non401(k) defined-contribution (DC) pension plans, defined-benefit (DB) pension plans, Social Security, housing equity, and taxable wealth.

5) Retirement-account wealth, defined as the sum of IRA, 401(k), and non-401(k) DC assets, and taxable wealth can be invested in risky stocks, with stochastic return $r^{s}$, and riskless bonds, and, in addition to the optimal asset allocation decision across the different forms of wealth, there is an optimal asset location decision, whereby the consumer must decide which assets to hold in taxable and tax-deferred forms.

6) The model specifies in detail non-linearities in the budget set induced by employer matching, the tax treatment of $401(\mathrm{k})$ and IRA contributions, respectively, IRA withdrawals, including the tax penalty for early withdrawals and minimum-distribution requirements, and the interrelationship between employer matching, 401(k) plan characteristics, and the price of leisure.

7) There are four liquidity constraints: a) non-401(k)-DC, DB and Social Security wealth are assumed illiquid until retirement and cannot be used as collateral (in accordance with federal law); b) there are constraints on the housing loan-to-value ratio for homeowners which limits the amount of mortgage debt that can be held; c) 401(k) wealth is assumed illiquid until retirement; and d) there is a cash-onhand constraint, such that total per period full expenditure (also referred to as "full income" in the two-stage budgeting literature), $y$, must be less than or equal to total net cash on hand, where the latter is defined as beginning-of-period liquid taxable wealth and other income on hand, plus the market value of the leisure endowment, less the tax liability, plus any IRA wealth made liquid through a withdrawal, less any tax-deferred saving in the form of contributions to the 401(k) and IRA.

8) In each period $t$, there are minimum- and maximum-contribution constraints on 401(k)s and IRAs (with multipliers in square brackets), respectively,

$$
Q_{t}^{V O L} \geq 0, \quad\left[\eta_{t}^{0}\right]
$$




$$
\begin{array}{ll}
Q_{t}^{V O L} \leq L_{t}^{V O L}, & {\left[\eta_{t}^{L}\right]} \\
Q_{t}^{I R A} \geq 0, & {\left[v_{t}^{0}\right]}
\end{array}
$$

and

$$
Q_{t}^{I R A} \leq L_{t}^{I R A}, \quad\left[v_{t}^{L}\right]
$$

where $Q^{V O L}$ denotes 401(k) contributions, $Q^{I R A C}$ denotes IRA contributions, and $L^{V O L}$ and $L^{I R A}$ are the upper limits on 401(k) and IRA contributions, respectively. $L^{I R A}$ is governed by federal law and depends on marital status and pension coverage; $L^{V O L}$ is governed by the employer's plan, but may not exceed the federal statutory maximum.

9) Each period when working, the consumer chooses consumption, leisure, voluntary 401(k) contributions, $Q^{V O L}$, IRA contributions, $Q^{I R A C}$, IRA withdrawals, the housing loan-to-value ratio, and the shares of retirement-account and taxable wealth held in risky stocks, respectively. Each period when retired, the consumer chooses consumption, IRA contributions, IRA withdrawals, the housing loan-tovalue ratio, and receives eligible pension and Social Security benefits.

To summarize, the only forms of "active" saving when working are through contributions to 401(k), IRA, or taxable assets; adjustments can be made to the mortgagedebt position as well. However, the primary technology for smoothing resources across periods when working is through taxable-asset saving, because 401(k) saving is illiquid; IRA contributions are not necessarily illiquid because of the availability of withdrawals, but IRA withdrawals may incur a tax penalty; traditional pensions and Social Security are illiquid; and the extent of mortgage borrowing is limited. This means that the consumer's optimization does not imply automatically that all active saving be allocated first to the tax-preferred asset with the highest net return, because, in the face of uncertainty, the consumer must balance the desire for a high return with the need for liquidity.

\section{First-Order Conditions}


As explained in the data section below, consumption and hours are not fully observed in the HRS, so that, from the perspective of the empirical analysis, it is desirable to work with the indirect, rather than the direct, utility function. Specifically, let $V(\mathbf{p}, y ; \mathbf{z})$ be the intratemporal indirect utility function. It takes as arguments the vector of prices of leisure and consumption, $\mathbf{p}$, full income, $y$, and the vector of demographics, $\mathbf{z}$. Following Browning, Deaton, and Irish (1985), let $\vartheta_{t}^{*}\left(W_{t}^{T}\right)$ be the sum of current and future expected utility based on total wealth in period $t$. The individual makes all decisions at the beginning of the period, based on the information set, $\Omega_{t}$, after which, $r^{s}$ is realized, $E$ is the expectations operator conditional on the information set, and $\beta$ is the discount rate.

The optimization is expressed in terms of two-stage budgeting. ${ }^{3}$ In the firststage, the individual chooses full income, dis-saving through IRA withdrawals, the mortgage-debt position, and the portfolio allocations to stock of retirement-account and taxable wealth, and must allocate total "active" saving to three asset categories-401(k), IRA, and taxable wealth-to maximize the expected present discounted value of lifetime indirect utility. In the second stage, optimal full income in each period is allocated statically between the goods that enter direct utility: consumption and leisure.

The first-order conditions when working for 401(k) contributions, IRA contributions, and full income can be expressed as

\footnotetext{
${ }^{3}$ The necessary condition for two-stage budgeting is that utility be weakly separable (Gorman, 1959). The model assumes strongly intertemporally and weakly intratemporally separable preferences, so that a twostage budgeting interpretation is valid.
} 


$$
\begin{aligned}
\eta_{t}^{L}-\eta_{t}^{0} & =E_{t}\left\{\left[R_{t}^{R A}\left(1+M_{Q_{t}^{401 k}}^{V}\right)-R_{t}^{T A}\left(1-T_{I t}\left(1-\zeta_{y_{t}} Q_{t}^{I R A}\right)\right)\right] \cdot\left[\rho_{t} \beta \vartheta_{W_{t+1}^{T}}^{*}+\left(1-\rho_{t}\right) \beta \Phi_{W_{t+1}^{T}}^{T}\right]\right\} \\
& -\mu_{t}\left(1-T_{I t}\left(1-\zeta_{y_{t}{ }_{t}} Q_{t}^{I R A}\right)\right), \\
v_{t}^{L}-v_{t}^{0} & =E_{t}\left\{\left[R_{t}^{R A}-R_{t}^{T A}\left(1-T_{I t} \zeta_{t}\right)\right] \cdot\left[\rho_{t} \beta \vartheta_{W_{t+1}^{T}}^{*}+\left(1-\rho_{t}\right) \beta \Phi_{W_{t+1}^{T}}\right]\right\}-\mu_{t}\left(1-T_{I t} \zeta_{t}\right),
\end{aligned}
$$

and

$$
V_{y}\left(\mathbf{p}_{t}, y_{t} ; \mathbf{z}\right)=E_{t}\left\{R_{t}^{T A}\left[\rho_{t} \beta \vartheta_{W_{t+1}^{T}}^{*}+\left(1-\rho_{t}\right) \beta \Phi_{W_{t+1}^{T}}^{T}\right]\right\}+\mu_{t}
$$

respectively. Note that subscripts indicate a partial derivative (other than $t$, which denotes time): for example, $T_{I}$ is simply the marginal tax rate; $M_{Q^{401 k}}^{V}$ is the marginal employer match rate for an additional dollar of $401(\mathrm{k})$ contribution; $\zeta$ is the fraction of IRA contributions that is federally tax-deductible; $\zeta_{y^{\prime}}$ is the change in the fraction of an IRA contribution that is deductible for an additional dollar of adjusted gross income (AGI); $V_{y}$ is the marginal utility of full income; $\mu_{t}$ is Kuhn-Tucker multiplier on the cash-on-hand constraint; and $R^{R A}$ and $R^{T A}$ are the weighted average returns on retirement-account and taxable wealth, respectively.

Even though the typical employer match yields a net return far exceeding that on other assets, so that it would appear obvious that the individual always would want to make the maximum possible contribution to the $401(\mathrm{k})$, equation (5) indicates the role of liquidity in the $401(\mathrm{k})$ contribution decision. In particular, there are two ways for this equation to be satisfied when contributions are less than the plan maximum even when the match and tax rates are positive, $M_{Q^{401 k}}^{V}>0$ and $T_{I}>0$, respectively, and these occur when the liquidity constraint binds, $\mu>0$ : (a) the corner solution of no $401(\mathrm{k})$ saving, 
for which the Kuhn-Tucker multipliers on the 401(k) contribution constraints in (1) and (2) are $\eta^{0}>0$ and $\eta^{L}=0$, respectively; and (b) an interior solution, for which $\eta^{0}=0$ and $\eta^{L}=0$ (i.e., the contribution is positive, but not at the plan maximum), and the multiplier on the liquidity constraint is large enough that the second term just equals the first term on the right-hand side of (5). A particularly important example of this latter case is when the contribution is less than the match cap and the employee leaves "money on the table" by not contributing up until the point the match is exhausted. Therefore, even in the presence of an employer match, binding liquidity constraints can explain why 401(k) participation can be less than 100 percent, contributions can be less than the plan maximum, and employees rationally can leave money on the table. This implication of the model is examined in Section VII below, in which reduced-form specifications are estimated to see whether variables used by others in the literature to measure liquidity constraints can explain who fails to contribute at least until the match is exhausted.

\section{Econometric Specification}

The major difficulty with the use of (5) as a direct basis for estimating the impact of employer matching on $401(\mathrm{k})$ participation is that most of elements on the right-hand side are not fully observed in survey data: who is liquidity constrained, $\mu$; expectations, $E$; the sum of future expected utility, $\mho^{*}$; bequest motives, $\Phi$; and the discount rate, $\beta$, for example. To overcome this, define the following tax/match prices, $p_{t}^{I R A} \equiv 1-T_{I t} \zeta_{t}$, $p_{t}^{m} \equiv 1+M_{Q_{t}^{401 k}}^{V}$, and $p_{t}^{401 k} \equiv 1-T_{I t}\left(1-\zeta_{y_{t}} Q_{t}^{I R A}\right)$, and then combine (5)-(7) to solve out for the unobserved elements to yield 


$$
\Delta \eta_{t}=\Delta p_{t} \cdot V_{y}\left(\mathbf{p}_{t}, y_{t} ; \mathbf{z}\right)+p_{t}^{m} \Delta v_{t},
$$

where $\Delta \eta_{t} \equiv \eta_{t}^{L}-\eta_{t}^{0}, \Delta v_{t} \equiv v_{t}^{L}-v_{t}^{0}$, and $\Delta p \equiv p^{m} p^{I R A}-p^{401 k} \cdot 4$

Equation (8) motivates the functional form for estimation. In particular, let the indirect utility function take the following form,

$$
V(\mathbf{p}, y ; \mathbf{z})=\Psi(\mathbf{z}) \cdot \frac{\ln (y)-\ln [a(\mathbf{p})]}{\ln [b(\mathbf{p})]},
$$

which is a member of the class of the PIGLOG indirect utility functions (Muellbauer, 1976), that has been used extensively in the literature on consumption. Following Blundell, Browning, and Meghir (1994), $\Psi$ is a utility scaling factor that is a function of the exogenous demographic characteristics. In (9), $b$ is homogeneous of degree zero and modeled as a Cobb-Douglas price aggregator

$$
b(\mathbf{p})=\prod_{k} p_{k}^{\gamma_{k}}
$$

across the $k$ goods that enter the direct utility function, where $\sum_{k} \gamma_{k}=0$. Because there are only two goods that enter direct utility, leisure $(k=1)$ and consumption $(k=2)$, respectively, this implies $\gamma_{2}=-\gamma_{1}$, so that (10) can be re-written as

$$
b(\mathbf{p})=\omega^{\gamma k},
$$

where $\omega \equiv p^{l} / p^{c}$ is the real relative price of leisure. In addition, $a$ is homogeneous of degree one. From (9), the marginal indirect utility of full income, $V_{y}$, is

$$
V_{y}=\left(\frac{\Psi(\mathbf{z})}{y \ln [b(\mathbf{p})]}\right) .
$$

\footnotetext{
${ }^{4}$ These three prices are not for goods that enter the intratemporal direct utility function and, therefore, are not in the price vector $\mathbf{p}$ that is an argument in the indirect utility function.
} 
The scaling factor $\Psi$ is modeled as

$$
\Psi_{i}(\mathbf{z})=\sum_{m} \psi_{m} z_{i, m}
$$

where $\mathbf{z}$ is an $m \times 1$ vector that includes a constant. The second term on the right-hand side of (8) is zero when IRA saving is at an interior solution, positive when constrained by the upper IRA limit, and negative when at the lower IRA limit (of zero). Finally, let

$$
\kappa \equiv p^{m}\left(D^{L^{I R A}}-D^{0}\right)
$$

where $D^{L^{I R A}}$ is a dummy variable that is one if IRA contributions, which are measured in the HRS, are at the upper limit and zero otherwise, and $D^{0}$ is a dummy variable that is one if IRA contributions are zero and zero otherwise.

Because, as will be illustrated in the discussion of the descriptive statistics, there is a very small percentage of workers in the sample whose contributions equal the $401(\mathrm{k})$ plan maximum, we first consider just the participation decision in the empirical analysis, so that $\Delta \eta$ collapses to $-\eta^{0}$, and (8), (12), (13), and (14) combine to yield the following discrete choice econometric model

$$
-\eta_{i j t}^{0}=\sum_{m} \delta_{1 m} z_{i, m} \frac{\Delta p_{i j t}}{y_{i j t} \ln \left(\omega_{i j t}\right)}+\delta_{2} \kappa_{i j t}+\boldsymbol{\alpha} \mathbf{x}_{i j t}+u_{j i t}
$$

and

$$
\begin{aligned}
& D_{i j t}^{V O L}=1 \text { if } Q_{i j t}^{V O L^{*}}>0 \Leftrightarrow-\eta_{i j t}^{0}=0 \\
& D_{i j t}^{V O L}=0 \text { if } Q_{i j t}^{V O L^{*}}=0 \Leftrightarrow-\eta_{i j t}^{0}<0,
\end{aligned}
$$

where $\delta_{1 m} \equiv \psi_{m} / \gamma_{1}, \quad Q_{i j t}^{V O L^{*}}$ denotes the desired 401(k) contribution, $i$ and $j$ index individuals and 401(k) plans, respectively, and $u$ is the error term. Alternatively, this framework lends itself naturally to a censored regression model of the determinants of the 
dollar amount of 401(k) saving (i.e., contributions), where at the upper contribution limit, $\Delta \eta>0, Q_{i j t}^{V O L^{*}} \geq L_{i j t}^{V O L}$, but $Q_{i j t}^{V O L}=L_{i j t}^{V O L}$, and at the lower contribution limit $\Delta \eta<0$, $Q_{i j t}^{V O L^{*}} \leq 0$, but $Q_{i j t}^{V O L}=0$. If an increase in the employer match raises participation, then the null hypothesis $\delta_{0}=\delta_{11}=\delta_{12}=\delta_{13}=\delta_{14}=\delta_{15}=\delta_{2}=0$ should be rejected, and the estimated marginal effects and elasticities of participation and saving to the match rate should be positive, respectively.

In the empirical analysis, $\mathbf{z}$ includes a constant, the worker's education (in years), age, and dummy variables for whether the worker was married, white, and female, respectively. These demographic characteristics enter parsimoniously and allow the impact of employer matching to be heterogeneous across demographic groups. The last term on the right-hand side of (15) includes $\mathbf{x}$, a vector that contains a constant and exogenous employer and employment characteristics. These are additional factors, explained in section $\mathrm{X}$ below, that fall outside of the scope of the theoretical framework, but may affect contributions. In the baseline specifications, $\mathbf{x}$ is limited to a constant; additional specifications allow the employer and employment characteristics to enter $\mathbf{x}$.

\section{Data}

Previous research primarily has used nationally representative, individual-level survey data, such as the Current Population Studies (CPS) and Surveys of Consumer Finances (SCF), which are plagued by two important sources of measurement error. First, even though the researcher must know the entire match schedule for a plan to account for the individual's full opportunity set, as well as whether the match is discretionary or through profit-sharing, the typical survey respondent has great difficulty 
in accurately conveying even relatively simple pension provisions to interviewers, no less detailed matching schedules. ${ }^{5}$ Second, self-reported contribution data also suffer from substantial reporting error. In addition, as the theoretical framework showed, the data required to model saving are quite extensive: contributions, components of household (including spousal) income, assets, debts, demographics, marginal tax rates, spousal pension coverage, and expected entitlements from Social Security and traditional pensions, which require lifetime and job earnings histories, respectively. Previous studies have not had all of these data.

In this paper, these problems are overcome by using remarkably detailed data from the first wave of the HRS, a nationally representative random sample of 51-61 year olds and their spouses (regardless of age). The first wave asked detailed questions about wealth (including IRA and taxable assets), demographics, and spousal characteristics in 1992. The survey also asked detailed questions about household income, tax information, and IRA contributions, but, as is true in many household surveys, these questions were for the previous calendar year, 1991. So, for the purposes of the empirical analysis, periods $t$ and $t+1$ refer to 1991 and 1992, respectively.

Questions on employment were asked for the job (if any) held at the time of the interview, as well as previous jobs. A unique feature of these data is that the HRS used the job rosters from the household interviews and collected Summary Plan Descriptions (SPDs), which are legal descriptions of pensions written in plain English, from employers of HRS respondents for all current and previous jobs in which the respondent was covered by a pension. These descriptions help to sidestep the problems with

\footnotetext{
${ }^{5}$ See Mitchell (1988), Starr-McCluer and Sunden (1999), Johnson, Sambamoorthi, and Crystal (2000), Gustman and Steinmeier (1999), Rohwedder (2003a, 2003b), and Engelhardt (2001) for evidence on measurement error in pension data.
} 
measurement error outlined above, and, instead, measure the exact incentives to contribute by using the employer matching formulas given in the SPD. ${ }^{6}$ Specifically, the job in which the respondent was employed in 1991 was identified and then SPDs associated with that job that had dates of adoption after 1991 were excluded. In addition, the date of last amendment and dates for changes in plan provisions indicated in the text of the SPD were used to exclude plans that were in existence in 1991 but whose features changed between 1991 and the time the SPD was collected.

The HRS also asked in the first wave the respondents' permission to link their survey responses to administrative earnings data from SSA and IRS. These administrative data include Social Security covered-earnings histories from 1951-1991 and W-2 earnings records for jobs held from 1980-1991, and were made available for use under a restricted-access confidential data agreement. They are the basis for two critical measures in the analysis dataset. First, the W-2 data provide administrative data on earnings and 401(k) contributions for 1991. Unlike the contributions data used in previous studies, these data are not subject to measurement error, as they are the employer's official report to the government on annual earnings and elective deferrals. Second, when combined, the W-2 earnings histories, Social Security covered-earnings histories and self-reported earnings histories, allowed for the construction of complete earnings histories from 1951-1991 for each member of our sample. When used with Social Security and pension-benefit calculators, which are described in Appendix B, these data allowed for the calculation of the public and private pension wealth, accruals and changes in accruals, for 1991 and 1992, respectively.

\footnotetext{
${ }^{6}$ The data appendix explains why self-reported pension information was not used and some other data limitations in the HRS.
} 
Overall, when all of the sources are combined, the data are a comprehensive description of the household's financial situation and exact pension incentives in 1991 and 1992 with which to estimate the parameters in the empirical specification in (15) and a significantly richer data source than previous studies. Specifically, the sample consists of 1,042 HRS individuals eligible to contribute to a 401(k) in 1991 .

\section{Descriptive Statistics}

Many plans limit the amount of the match. These caps are usually expressed as a percent of pay in the SPD, but also can be a percent of contributions, and even a fixeddollar amount. Table 1 shows the distribution of matching caps in the analysis sample, expressed as a percent of annual pay. About 19 percent of these plans had caps on employer matching that were less than four percent of pay. The median cap was 6 percent of pay, but 15 percent of plans had higher caps. Plans also vary according to the match rate. Table 2 shows the distribution of "first-dollar" match rates in the analysis sample. Columns 1 and 2 indicate that these match rates were clustered at 25, 50, and 100 percent, where the median match rate was 50 percent. However, 27 percent of the plans offered matches of 100 percent, and three plans offered match rates of 200 percent.

Descriptive statistics for selected variables used in the empirical analysis are shown in Table 3. Column 1 shows sample means for the full sample, with the standard deviation in parentheses, and the median in square brackets. Overall, the sample consists of mostly white, married individuals in their mid-50s, with some college education and relatively few children at home. Only 56.4 percent of the sample actively participated (defined as having made a positive contribution) in 1991. The sample mean 401(k) 
contribution in calendar year 1991 was $\$ 1,377$, but among contributors, the average contribution was $\$ 2,446$ (shown in column 4). Only 3 percent of the sample made the maximum contribution.

Figure 1 plots the distribution of $401(\mathrm{k})$ contributions for the match-eligible individuals in the sample in intervals of $\$ 200$ relative to the kink amount. As illustrated in the figure, there is substantial bunching of contributions at the kink (measured as the value 0 on the horizontal axis). About 25 percent of match-eligible individuals locate at or within $\$ 400$ of the kink on their budget sets.

A comparison of contributions between those without and with employer matching in columns 2 and 3 of Table 3, respectively, indicates that individuals with matching contributed just over $\$ 400$ more on average than those without matching (i.e., $\$ 1,640-\$ 1,232=\$ 408)$. The difference in the median contributions between these two groups was $\$ 800$. Therefore, just based on a comparison of means, it would appear that there is a small response of $401(\mathrm{k})$ saving to matching.

A comparison of columns 2 and 3 in Table 3 also indicates that plans with employer matching differ along other dimensions that may make saving attractive. For example, if there is an employer match, the individual is much more likely to be able to borrow against the plan balance, direct the investment of plan balances, less likely to have another traditional pension plan, more likely to have the plan annual contribution limit lower than the federal limit, and more likely to be allowed to make after-tax contributions to the plan.

\section{Explaining Unused Employer Matching Contributions}


Because the typical employer match yields a return far exceeding that on alternative investments, $401(\mathrm{k})$ participation would be predicted to be 100 percent if all individuals were fully informed, financially rational, with access to perfect capital markets and no transactions costs. In addition, at a minimum, all participants would be predicted to maximize total compensation and contribute up to the point at which the employer match was exhausted and then engage in a set of borrowing and lending arrangements to achieve the desired level of consumption and leisure. ${ }^{7}$ Yet in Table 3, 401(k) participation is 56.4 percent among all sample individuals, and only 54 percent among those offered a match. This suggests that individuals left "money on the table" by not capturing the total potential employer match.

Column 1 of Table 4 shows the total potential employer match in the sample for individuals eligible for a match. The mean potential match was $\$ 1,249$, or 3.8 percent of annual pay. The average employer match that went unused because contributions were not made up to the level of the match cap was $\$ 550$, or 1.9 percent of pay. Naturally, non-participants accounted for most of this, with the unused match equal to 3.7 percent of pay (column 3). Even more striking, though, is that among participants the average unused employer match represented 1 percent of pay (column 2). ${ }^{8}$

As described in the theoretical framework, one possible explanation for this is that individuals were liquidity constrained. To explore this, ad hoc reduced-form models were estimated measuring whether and to what extent the $401(\mathrm{k})$ contribution was less than the cap on the employer match as a function of a set of explanatory variables that

\footnotetext{
${ }^{7}$ A similar argument would imply that all individuals would be predicted to contribute up to the plan limit, and engage in a set of borrowing and lending arrangements to achieve the desired consumption and leisure, and thus exploit the tax arbitrage from deferral to minimize the lifetime tax liability.

${ }^{8}$ Choi et al. (2005) and Mitchell, Utkus, and Yang (2005) have similar findings using various sets of company data.
} 
measure (to varying degrees) the ability to borrow, which have been used by others in the previous literature on liquidity constraints, but none of which measure such constraints definitively: demographics (white, age, married, and years of education); dummy variables for whether the household has no capital income; has access to borrowing against home equity through a home equity line of credit, conditional on being a home owner; has experienced financial distress in the past due to unanticipated medical expenses and unemployment, respectively; and has access to informal private support from friends and family if under financial distress. ${ }^{9}$

The results are shown in Table 5 for the sub-sample of individuals offered a match. Sub-sample means are shown in column 1. Column 2 shows estimates from a probit model in which the dependent variable is one if the individual contributed below the employer match cap (including a zero contribution) and zero otherwise. Individuals who were more educated or with a home equity line of credit were statistically significantly less likely to have contributed below that match cap, whereas those individuals who had financial distress from unanticipated medical expenses or no capital income were statistically significantly more likely to have contributed below that match cap. Columns 3 and 4 show estimates for Tobit models of the dollar amount and the percentage of pay of the unused employer match, respectively, and the results are qualitatively similar. These results are not inconsistent with the theoretical result that

\footnotetext{
9 This section of the paper includes the results of ad hoc reduced-form models of the impact of liquidity constraints on "money on the table" only to provide some evidence in support of (or at least not inconsistent with) the mechanism in the theoretical framework that would explain individuals' failure to fully exploit the employer matching and tax-deferral in 401(k)s - namely, liquidity constraints. In particular, measures of liquidity constraints used by others in the literature are used here simply for comparative purposes. There are at least two other explanations for the presence of unused employer matching contributions, imperfect information and present-biased preferences, both of which we discuss in the appendix.
} 
constrained borrowing is a plausible explanation for why workers fail to capture the total potential employer match.

\section{Ad Hoc Reduced-Form Estimation Results}

To compare the non-linear budget set approach with that from the previous literature, this section gives the estimation results from a series of ad hoc reduced-form specifications similar in spirit to those in the literature, using the same estimators as used in the literature, but with the HRS data. Selected parameter estimates are shown in Table 6. Standard errors are in parentheses.

Column 1 shows a probit specification for the decision to contribute to the $401(\mathrm{k})$ plan in 1991. In columns 2-4, the dependent variable is the dollar amount of contributions. Contributions are modeled as a function of earnings, demographics, a dummy for whether the firm matches contributions and the marginal match rate in column 2. Column 3 expands the specification to include quartic functions in age and earnings. Column 4 presents one-limit Tobit estimates. Like previous studies, all specifications in the table indicate that the presence of a match raises contributions. However, conditional on offering a match, the point estimates suggest that increases in the match rate may increase or decrease contributions, but none of these effects are statistically significant. The estimated elasticity of contributions with respect to the match rate (conditional on having been offered a match) is shown in the last row of the table for each specification, with standard errors in parentheses.

\section{Estimation and Identification in the Non-Linear Budget Set Framework}


The estimation of the parameters in (15) employs an instrumental-variable technique that linearizes the budget set at the observed outcome to calculate the price and virtual income terms and then instruments to correct for endogeneity. In particular, for all observed 401(k)-contribution outcomes in the dataset, the tax and match prices, $p^{I R A}$, $p^{m}$, and $p^{401 k}$, the net wage, $\omega$, and full income, $y$, must be calculated in order to construct $\Delta p / y \ln (\omega)$ and $\kappa$ in (18). Because budget-set slopes are not defined at kink points, a variant of the method of MaCurdy, Green, and Paarsch (1990) was used to calculate $p^{I R A}, p^{m}$, and $p^{401 k}$ for each individual in the sample. Specifically, the matching formulas in the SPDs, tax-rate information from NBER's TAXSIM calculator, and detailed household financial and demographic characteristics were used to lay out the budget set in detail, then the kinks in the budget set were smoothed non-parametrically using kernel regression of the implicit (negative) tax rate from the employer matching and tax subsidy to contributions on AGI over the federal legally allowable range of 401(k) contributions of 0 to $\$ 9500$ using a second-order Gaussian kernel, $K(z)=(1 / \sqrt{2 \pi}) e^{-z^{2} / 2}$, with bandwidth chosen by Silverman's rule of thumb, $h=0.9 m / n^{1 / 5}$, where $m=\min \left(\sqrt{\operatorname{var}_{x}}, i q r_{x} / 1.349\right)$ and $i q r_{x}$ is the inter-quartile range. ${ }^{10}$ This regression was done on an individual-by-individual basis, so that the smoothing is individual-budget-set specific, and the estimates allow for budget-set slopes to be measured for those individuals located at kink points.

Full income, $y$, can be expressed as

$$
y_{i t} \equiv \Delta A_{i t}^{T A}+w_{i t} L^{l}+y_{i t}^{o}-Q_{i t}^{V O L}-Q_{i t}^{I R A C}+Q_{i t}^{I R A W}-T_{i t} \text {, }
$$

\footnotetext{
${ }^{10}$ See Appendix A for details.
} 
and includes the market value of the leisure endowment. Under two-stage budgeting, the capital income and net (dis-)saving terms embodied in $\Delta A$ are sufficient statistics for the past and the expectations of future variables (Blundell and Macurdy, 1999). Because of the non-linear structure of matching and marginal tax rates, the tax and match prices, $p^{I R A}, p^{m}$, and $p^{401 k}$, change depending upon the budget-set segment (either because the marginal match rate or tax rate changes), and, hence, the taxes-paid measure, $T$, which, in turn, incorporates the dollar amount of the implicit tax liability from the employermatching and tax subsidies, will change depending upon the budget-set segment as well. Therefore, full income is actually measured as "virtual" full income, $y^{v}$, according to the respective budget segment, where $T^{v}$ denotes the associated implicit tax liability, which is calculated by numerically integrating the estimated kernel-smoothed implicit tax function described above.

Unfortunately, the explanatory variables in (18) have components based on choice variables. Therefore, the instrument set, $\mathbf{Z}$, includes the vector of demographics, $\mathbf{z}$, and three additional variables, $Z_{i t-1}^{F C}, p^{m z} \cdot p^{I R A z}$, and $p^{401 k z}:$ the first is a dummy variable if the household was in poor financial condition in 1990, and the second and the third are based on "first-dollar" match and marginal tax rates for a synthetic taxpayer in $1989 .{ }^{11}$ There are two primary sources of variation in the instruments. First, $p^{m z}$ varies by plan, $j$. That is, it is assumed that the variation in matching schedules across plans is exogenous. Second, $p^{I R A z}$ and $p^{401 k z}$ vary across synthetic individuals because the tax

\footnotetext{
${ }^{11}$ We also estimated the model by additionally controlling for directly for demographic characteristics by including the vector $\mathbf{z}$ in $\mathbf{x}$. We could not reject the null hypothesis that these additional variables jointly had no impact on $401(\mathrm{k})$ participation. This suggests that the demographic characteristics do not have an effect separate from their interactions with the matching terms. We do not report these results, but they are available upon request.
} 
function is non-linear in income and marital status. Appendix B gives a detailed description of the construction of the instruments and discusses the sources of identification in detail.

A final issue is that the sample is likely non-random because it is based on individuals for whom the HRS was able to obtain an employer-provided SPD for the 401(k) plan. Although previous pension studies using the HRS employer-provided SPDs have not corrected for selection because of the lack of plausible exclusion restrictions, two exclusion restrictions based on IRS Form 5500 data were used to estimate the model using a number of methods to correct for selection. The first exclusion is the incidence of pension-plan outsourcing by Census region, employment-size category, one-digit SIC code, and union status (union plan vs. non-union plan) cell in 1992, where outsourcing means the plan was administered by an entity other than the employer. The intuition is that the HRS is less likely to obtain an SPD from the employer if (on average in its cell) plan administration is outsourced, because more than one contact is needed (first the employer, then the plan administrator) to receive the SPD. The second exclusion is the incidence of pension-plan consolidation due to mergers and acquisitions by cell from 1988-1992. The intuition is that the HRS is less likely either to obtain an SPD from the employer or match it to the employee if (on average in its cell) there has been a lot of plan consolidation, because plan names and detail are often changed upon consolidation. Finally, two other variables based on HRS data were used as exclusions in the selection equations: dummies for whether the individual left the job because the business closed or was laid off, respectively. These help to measure whether the employer possibly was in financial difficulty at severance, which, if that resulted in a business failure, would have 
made it more difficult for the HRS to have obtained an SPD. The construction of the exclusions and the selection equation are discussed in detail in Appendix B.

\section{Estimation Results}

The parameters in (15) are estimated in the baseline specification, in which the vector $\mathbf{x}$ in is limited to a constant, by maximum likelihood, where $u \sim N\left(0, \sigma^{2}\right)$. Panel A of Table 7 presents parameter estimates with standard errors in parentheses. ${ }^{12}$ Panel B lists the set of additional explanatory variables in the models. Column 1 shows the parameter estimates for the baseline specification without instrumenting. The marginal effect for a one unit change in the match rate represents an increase of one dollar of match per dollar of employee contribution and is shown in Panel. ${ }^{13}$ The estimated marginal effect of an increase in the match rate by one dollar is an increase in participation of 0.0091 or nine-tenths of a percentage point, which is economically extremely small and statistically different than zero, based on the $p$-value for the test of the null hypothesis of no impact of employer matching shown in panel A. The estimated marginal effect for virtual full income is negative, consistent with consumption and leisure as normal goods, statistically significantly different than zero, but, again, the economic magnitude of the income elasticity is very small.

Column 2 gives the instrumental-variable estimates. In panel B, an increase in the match rate of one dollar increases contributions by an estimated 27 percentage points and is statistically different than zero. This estimate is substantially larger than the one in column 1 without instrumenting, which indicates substantial downward bias in the

12 The standard errors account for the presence of the estimated selection-correction and the use of instrumental variables.

${ }^{13}$ The $95 \%$ bias-corrected bootstrapped confidence interval is shown in square brackets. 
estimated match effect from endogeneity. In column 2, the income effect is negative and indicates that an increase of one unit in virtual full income, which represents an increase of $\$ 100,000$, results in an estimated reduction in the probability of participation of eight percentage points. The income effect, as well as the impact of the net wage and the marginal tax rate, are all significant at less than the 0.0001 level of significance for all of the specifications in Table 7.

To get a better sense of the economic magnitude of these marginal effects, Panel D shows the estimated elasticity of participation with respect to the employer match rate, evaluated at the sample means. In column 2, the estimated elasticity is 0.07 : if the employer match were raised from twenty-five to fifty cents (i.e., doubled), participation would rise by seven percent (not percentage points). ${ }^{14} \quad$ Thus, 401(k) participation appears to be quite inelastic with respect to the employer match. The estimated income elasticity is -0.10 ; the estimated net wage elasticity is -0.04 ; and the estimated elasticity with respect to the marginal tax rate is 0.04 , so that $401(\mathrm{k})$ participation also is very inelastic with respect to the tax price.

Panel A also shows the parameter estimates on the exclusion restrictions in the selection model. ${ }^{15}$ The $p$-value for the test of the null hypothesis that the exclusions jointly do not explain who has a matched SPD, though not shown in the table, is less than 0.01 , which indicates the exclusions have predictive power for who is in the sample. In particular, greater plan outsourcing, consolidation, business closure and layoffs significantly decrease the likelihood of having a matched SPD. The parameter estimate on the selection term in the participation equation is negative, and, based on the

\footnotetext{
${ }^{14}$ The estimated elasticities are very similar when based on individual characteristics.

15 Parameter estimates for the full selection model are available upon request.
} 
associated standard error, the null hypothesis of no selection bias can be rejected at the 3 percent level of significance. This is evidence of selection: high savers are less likely to have an employer-provided SPD in the HRS, consistent with the reduced-form analysis of Gustman and Steinmeier (1999). To gauge whether this selection is economically important, column 3 shows the IV results without selection correction. The estimated participation elasticity with respect to the match rate in Panel E is now 0.19 , which is more than double the selection-corrected elasticity of 0.07 in column 2. This indicates that the bias from estimating the determinants of $401(\mathrm{k})$ participation on the selected sample of the respondents in the HRS who have matched SPDs has a substantial effect on the economic magnitude of the employer match estimates.

\section{Robustness Checks and Extensions}

There are two practical concerns in the estimation that fall outside of the scope of the theoretical framework. First, firms may offer employer matching contributions as a way to try to avoid failing federal pension non-discrimination rules because they have low-saving employees (McGill, et al., 1996). This would tend to bias downward the estimated match elasticity. Second, firms that match may adopt other plan features to stimulate employee saving (e.g., allow for borrowing against plan balances, self-directed investment, offer after-tax saving options, offer retirement seminars, etc.) or offer different fringe benefit packages that might affect saving behavior than firms that do not match. This would tend to bias upward the estimated match elasticity.

The reduced-form relationship between employer match rates and these factors using the HRS data was examined in a companion paper, Engelhardt and Kumar (2004a). 
As described there, the non-discrimination rules are set up so that employers with a greater proportion of workers with earnings large enough to be deemed "highlycompensated employees" under federal law face greater pressure to meet nondiscrimination rules if they offer a $401(\mathrm{k})$. In particular, a variable that measured the share of workers with earnings above the federal threshold for the definition of a "highlycompensated" employee under federal non-discrimination regulations in the respondent's Census-region-by-employment-size-category-by-one-digit-SIC-code-by-union-status cell in 1989 was constructed from the March CPS. This measure was then weighted by the difference in combined federal and state marginal tax rates on earnings for the median highly- and non-highly-compensated workers in the cell to reflect the value a highlycompensated worker would put on a dollar of tax-deferred salary through a $401(\mathrm{k})$ relative to that for a non-highly-compensated worker. This tax-difference-weighted share was used as a measure of the non-discrimination "pressure" faced by the typical employer in the respondent's cell in a reduced-form model of the determinants of match rates in the HRS data.

The estimation results in Engelhardt and Kumar (2004a) showed that the measure of pressure and other plan characteristics were highly significant. For example, the greater the pressure (tax-difference-weighted share) the more likely the respondent's plan offered a match and the higher the match rate. Also, plans that allowed borrowing, selfdirected investment, had other traditional features, had limits less than the federal limit, and after-tax saving options had significantly higher first-dollar employer match rates, as 
was suggested in the comparison of unconditional means in Table 3 of the current paper. $^{16}$

With this in mind, two groups of additional explanatory variables were included in the vector $\mathbf{x}$ in (15) for the specification in Table 7: 1) fringe benefits offered: dummy variables for whether the firm offered long-term disability and group term life insurance, respectively, as well as the number of health insurance plans, number of retiree health insurance plans, weeks paid vacation, and days of sick pay; 2) other plan characteristics: dummy variables for whether the 401(k) allowed borrowing, hardship withdrawals, selfdirected investment, had an after-tax saving option, a 401(k) contribution limit less than the federal limit, respectively, whether the firm offered other traditional pensions, and the measure of non-discrimination "pressure" described above.

Column 4 Table 7 shows the estimation results for this specification. In particular, in panel B, the estimated marginal effect of a one-dollar increase in the match rate is an increase in participation of 0.09 , or nine percentage points. The estimated match rate elasticity, Panel E, is 0.02 , compared to 0.07 in column 2 , so that the addition of the fringe benefit and other plan characteristics has an important impact on the results. The estimated marginal effects for income, net wage, and the marginal tax rate also decline relative to those in the baseline specifications in column 2 .

In column 5, a third set of explanatory variables was added to $\mathbf{x}$ in (15): 3) additional employment characteristics: dummy variables for both the worker and spouse for whether the firm offered a retirement seminar, discussed retirement with co-workers,

\footnotetext{
${ }^{16}$ Another potential concern is that high-saving individuals, such as those with long horizons, might sort to firms that offer employer matching contributions (Ippolito, 1997). This would tend to bias upward the estimated elasticity of voluntary contributions to matching. However, the estimation results in Engelhardt and Kumar (2004a) showed no correlation of the employer match rate with measures of the demographics and horizon and offered no support for endogenous sorting.
} 
whether responsible for the pay and promotion of others, the number of supervisees, spousal pension coverage, as well as controls for firm size, Census division, and union status. These additional employment characteristics were interacted with the fringe benefit and plan characteristics described above to allow a more flexible functional form for $\alpha \mathbf{x}$ in (15). The estimated marginal effects for the match rate, income, net wage, and marginal tax rate are shown in column 5, respectively, are similar to those in the baseline specifications in columns 2 and 4, respectively. The estimated elasticity of participation to the match rate rises to 0.05 in Panel E.

Finally, to allow for a significantly more flexible functional form for $\alpha \mathbf{x}$ in (15), in column 6, occupation dummies were added; the fringe benefit, plan, and other employment characteristics were interacted with occupation; and, the other plan characteristics were interacted with the fringe benefit variables. Hence, the specification in column 6 is essentially fully interactive in the elements of $\mathbf{x}$. The estimated elasticity of participation to the match rate rises to 0.06 (column 6, Panel E).

As noted in section IV, the demographic characteristics enter (15) parsimoniously, in a manner that allows the impact of employer matching to be heterogeneous across demographic groups. Across columns in Table 7, the demographic group for which the employer match consistently appears to have statistically significant differential effects on contributions is the relatively highly educated. To highlight any differences in responsiveness across groups, Table 8 shows the estimated marginal effect and elasticities for the employer match rate by sex and education group for the richest specification, shown in column 6 of Table 7. In columns 1 and 2 of Table 8 , an increase in the match rate of one dollar increases participation of females and males by an 
estimated 22.6 and 17.5 percentage points, respectively. However, the estimated 95\% confidence intervals around these estimates overlap substantially and these effects are not statistically different from each other. In columns 3-7, the marginal effect as well as elasticities rises sharply by education group. ${ }^{17}$

\section{Estimates from the Censored Regression Model}

We also estimated (15) as a two-limit censored regression model of 401(k) saving in an instrumental-variable Tobit framework using the estimator of Newey (1986, 1987b), which allowed us to decompose the overall saving responses between the extensive and the intensive margins, respectively, based on the method of McDonald and Moffitt (1980). In addition, we used an instrumental-variable version of the Symmetrically Censored Least Squares (SCLS) estimator of Powell (1986) and Newey $(1986,1987 b)$. The primary advantage of this semi-parametric estimator is that it robust to heteroscedasticity and any departures to normality that were assumed for the Tobit error term.

${ }^{17}$ The marginal effect and elasticity with respect to the match rate rises monotonically with education until college degree. For those with graduate degrees, however, the elasticity is lower even though marginal effects are higher. This is due to lower match rate and higher participation rates at which the elasticity has been calculated for this group. In addition to the robustness checks indicated in Table 7, specifications were estimated based on the more general Box-Cox functional form for indirect utility from Blundell, Browning, and Meghir (1994),

$$
V(\mathbf{p}, y ; \mathbf{z})=\frac{\left(\frac{y}{a(\mathbf{p})}\right)^{\lambda}-1}{\lambda} \cdot\left(\frac{\Psi(\mathbf{z})}{\ln [b(\mathbf{p})]}\right),
$$

which nests the PIGLOG function we use. These results, which appeared in the version of the paper presented at the TAPES conference, were very consistent with the results shown in Tables 7 and 8, and, therefore, were not included in the current version for the purposes of exposition. They are available from the authors upon request. 
Table 9 presents a parallel set of results from the censored specification to those in Table 7 for the discrete choice model of participation. ${ }^{18}$ Overall, the general pattern of estimated responses is very similar to those from the binary choice specification in Table 7. Panel E shows the decomposition of the total elasticities into elasticities along the extensive (participation) and intensive (contributions conditional on participation) margins, respectively. ${ }^{19}$ Columns 5 and 6 present results from the richest specification using IV Tobit and IV SCLS, respectively. The latent marginal effects from the parametric and semi-parametric estimates in these two columns indicate that an increase in the match rate by one dollar per dollar of employee contribution raises $401(\mathrm{k})$ saving by $\$ 2261$ and $\$ 1522$ (in 1991 dollars) respectively. The estimated elasticity of contributions to the match rate is 0.12 (column 5, Panel E), with more than one half of this elasticity on the extensive margin which suggests that participation is relatively more responsive to variation in the employer match than contributions. The elasticities on the extensive (participation) margin are very similar the estimates from the discrete choice

18 The estimation uses methods laid out in Vella (1992) and Das, Newey, and Vella (2003) for the Tobit and SCLS estimators, respectively, to correct for potential sample selection. Parameter estimates for the full selection model are available upon request. The first-stage regressions for the endogenous variables in (15) were selection corrected as well.

${ }_{19}$ One drawback of the SCLS estimator is that the total, extensive-, and intensive-margin match rate elasticities shown in panel $\mathrm{E}$ cannot be calculated from the estimates. In addition to SCLS, the specifications were estimated using an instrumental-variable version of Powell's CLAD estimator extended to allow for two limits, with the upper limit varying across individuals, as is dictated by these data, accounting for selection using the method of Blundell and Powell (2004) for semiparametric estimators. The CLAD point estimates produced marginal effects that were very similar to the SCLS and Tobit estimated marginal effects shown in Table 8. However, when bootstrapping the standard errors, the estimator frequently failed to converge. In particular, as is well-known for LAD estimators, the estimator can fail to converge when the specification becomes more and more saturated with control variables and the cells become thin, as in the richer specifications in subsequent columns in Table 8 . This is a particularly severe problem for CLAD estimators that rely on iterative trimming of the data when the analysis dataset is not large, because the estimation dataset becomes smaller with each iteration, even though the number of explanatory variables remains the same. In this application, the estimation algorithm trimmed the original 1,042 observations down to around 400 by the last iteration. For this reason, reliable bootstrapped standard errors were not able to be obtained for CLAD estimates and they are not shown in Table 8. 
participation model in Table 7. Finally, Based on a Hausman-type test (Newey, 1987a), we could not reject the IV Tobit model in favor of the IV SCLS specification.

Table 10 shows the estimated marginal effect and elasticities for the employer match rate by sex and education group for the richest specification, shown in column 10 of Table 9. In columns 1 and 2 of Table 10, an increase in the match rate of one dollar increases contributions of females and males by an estimated $\$ 1,153$ and $\$ 1,752$, respectively. The results for the education groups echo those from the discrete choice model of participation in Table 8 , both marginal effects and elasticities rise sharply with education.

\section{Summary and Implications}

Previous studies have produced a puzzling array of estimates of the impact of employer matching on $401(\mathrm{k})$ saving. This probably stemmed from the use of less than ideal data and, more importantly, the failure to incorporate into estimation match-induced kinks in the budget set. Overall in this analysis, based on the life-cycle consistent specification derived, the estimated elasticity of $401(\mathrm{k})$ participation with respect to the match rate ranged from $0.02-0.07$, and, hence, participation was quite inelastic with respect to employer matching, a pattern that was apparent even in a simple comparison of means. The estimated elasticities of $401(\mathrm{k})$ saving from a censored regression model ranged from 0.09-0.12 with just under half of this response on the intensive margin.

There are two obvious limitations of these findings. First, the focus was on older workers, for whom the very detailed data for this type of study were available; whether the estimates apply to younger workers is an open question. Second, this study has 
nothing to say about the broader question of to what extent $401(\mathrm{k})$ saving constitutes new private saving, a point of substantial debate in the literature.

Given these caveats, there are a number of potential implications of these findings. First, because of the estimated inelastic response on both the intensive and the extensive margins, the analysis reveals that for employers and policy makers interested in promoting retirement saving by older workers through greater $401(\mathrm{k})$ participation and saving, matching is a rather poor policy instrument. Roughly speaking, the estimated marginal effects in this paper suggest that an increase in the employer match rate of $\$ 1$ per $\$ 1$ of employee contribution would be needed to achieve the same increase in participation as the implementation of automatic enrollment, based on the estimates in Madrian and Shea (2001) and Choi, Laibson, Madrian, and Metrick (2002, 2004). Automatic enrollment would seem to be a much more effective way to increase retirement saving. Second, a number of commonly-advocated reforms to Social Security call for the introduction of voluntary private accounts, to which individuals could choose to contribute additional funds toward Social Security. Under some proposals, the federal government would match those contributions as an incentive. In designing such a system, it would be instrumental for policy makers to know how individual contributions would respond to the government match. Our analysis suggests that government matching of voluntary contributions to any type of Social Security personal account would be relatively ineffective in promoting personal-account contributions (Engelhardt and Kumar, 2005). Third, beyond personal accounts, there is substantial policy interest in the government provision of matching contributions designed to stimulate targeted forms of saving among lower income households, which has led researchers to evaluate 
the impact of Individual Development Accounts (IDA) [Mills, Gale, Patterson, and Apostolov, 2006], federal programs for matching IRA contributions, and the adoption of the Saver's Credit [Duflo, Gale, Liebman, Orszag, and Saez, 2006]. In particular, the Mills, et al. and Duflo, et al. analyses, which were based on randomized field experiments, have shown substantially more elastic responses from matching contributions on IDA and IRA contributions, respectively.

Our reading of these two studies suggests that their findings are difficult to extrapolate to employer matching contributions in corporate 401(k) plans for three reasons. First, eligible employees in 401(k) plans are not typically lower income individuals. They are more likely to be substantially better off economically. For example, individuals in the Mills et al. analysis had incomes below 150 percent of the poverty line. Second, institutional features differ substantially. For example, contributions to a $401(\mathrm{k})$ plan that are matched are typically done through automatic payroll deduction, whereas contributions to IDAs and IRAs in the Mills, et al. and Duflo, et al. analyses were not. Third, the matching contributions in the Duflo, et al. analysis were offered as part of an unannounced, take-it-or-leave-it decision, whereas employees in a 401(k) can respond to a match by contributing at any point in a given calendar year, or even a different calendar year, without foregoing the option of being eligible for a match. Overall, although these are fascinating studies that will have important implications for policy targeted to lower income households and, through randomization, have convincingly addressed important issues in the econometric identification of the causal effects of matching, these studies are of limited use in formulating policy concerning 401(k) plans. 
Finally, a number of prominent companies have reduced or eliminated matching contributions recently due to declining profits. Although it remains to be seen if this is a long-term trend, understanding the impact of matching is critical to understanding the impact of these changes on retirement income security for a workforce increasingly dependent on $401(\mathrm{k})$ plans for retirement. The fact that the estimated response of contributions to the employer match in this paper was quite inelastic suggests that overall 401(k) activity at these firms might not be greatly affected by these changes in matching. 


\section{References}

Agnew, Julie, Pierluigi Balduzzi, and Annika Sunden, "Portfolio Choice and Trading in a Large 401(k) Plan," American Economic Review 93:1 (2003): 193-215.

Amronin, Gene, Jennifer Huang, and Clemens Sialm, "The Tradeoff between Mortgage Prepayments and Tax-Deferred Retirement Savings," Mimeo., University of Michigan, 2006.

Andrews, Emily S., "The Growth and Distribution of 401(k) Plans," in Trends in Pensions 1992, John A. Turner and Daniel J. Beller, eds. (Washington, DC: U.S. Department of Labor) 1992, pp. 149-176.

Attanasio, Orazio P., and Guglielmo Weber, "Is Consumption Growth Consistent with Intertemporal Optimization? Evidence from the Consumer Expenditure Survey," Journal of Political Economy 103:6 (1995): 1121-1157.

Barksy, Robert B., F. Thomas Juster, Miles S. Kimball, and Matthew D. Shapiro, "Preference Parameters and Behavioral Heterogeneity: An Experimental Approach in the Health and Retirement Study," Quarterly Journal of Economics 112:2 (1998): 537-580.

Bassett, William F., Michael J. Fleming, and Anthony P. Rodrigues, "How Workers Use 401(k) Plans: The Participation, Contribution, and Withdrawal Decisions," National Tax Journal 51:2 (1998): 263-289.

Bayer, Patrick J., B. Douglas Bernheim, and John Karl Scholz, "The Effects of Financial Education in the Workplace: Evidence from a Survey of Employers," NBER Working Paper No. 5655, 1996.

Benartzi, Shlomo, and Richard H. Thaler, "Naïve Diversification Strategies in Defined Contribution Saving Plans," American Economic Review 91:1 (2001): 79-98.

Benartzi, Shlomo, and Richard H. Thaler, "Save More Tomorrow: Using Behaviorial Economics to Increase Employee Saving," Journal of Political Economy 112: S1 (2004): S164-S187.

Bernheim, B. Douglas, "Taxation and Saving," in Alan J. Auerbach and Martin Feldstein, eds., Handbook of Public Economics, Volume 3 (Amsterdam: North Holland), 2003, pp. 1173-1249.

Bernheim, B. Douglas, and Daniel M. Garrett, "The Effects of Financial Education in the Workplace: Evidence from a Survey of Households," Journal of Public Economics 87 (2003): 1487-1519. 
Bernheim, B. Douglas, Daniel M. Garrett, and Dean M. Maki, "Education and Saving: The Long-Term Effects of High School Curriculum Mandates," Journal of Public Economics 80 (2001): 435-465.

Blomquist, Soren, and Whitney Newey, "Nonparametric Estimation with Nonlinear Budget Sets," Econometrica 70 (2002): 2455-2480.

Blundell, Richard, Martin Browning, and Costas Meghir, "Consumer Demand and the Life-Cycle Allocation of Expenditures," Review of Economic Studies 61:1 (1994): 57-80.

Blundell, Richard, and Thomas MaCurdy, "Labor Supply: A Review of Alternative Approaches," in Orley Ashenfelter and David Card, eds., Handbook of Labor Economics, Volume 3A, (Amsterdam: North Holland), 1999, pp. 1559-1695.

Blundell, Richard W., and James L. Powell, "Endogeneity in Semiparametric Binary Response Models," Review of Economic Studies 71:3 (2004): 655-680.

Brown, Jeffrey R., Nellie Liang, and Scott Weisbenner, "401(k) Matching Contributions in Company Stock: Costs and Benefits for Firms and Workers," NBER Working Paper No. 10419, 2004, forthcoming in the Journal of Public Economics.

Browning, Martin, Angus Deaton, and Margaret Irish, "A Profitable Approach to Labor Supply and Commodity Demands over the Life-Cycle," Econometrica 55:3 (1985): 503544.

Buchinsky, M., "Changes in the U.S. Wage Structure 1963-1987: Application of Quantile Regression," Econometrica, 62(2) (1994): 405-459.

Burtless, Gary, and Jerry Hausman, "The Effect of Taxation on Labor Supply: Evaluating the Gary Income Maintenance Experiment," Journal of Political Economy 86 (1978): 1103-1130.

Campbell, John Y., and Joao Cocco, "Household Risk Management and Optimal Mortgage Choice," Quarterly Journal of Economics 118:4 (2003): 1449-1494.

Carroll, Christopher D., "The Buffer-Stock Theory of Saving: Some Macroeconomic Evidence," Brookings Papers on Economic Activity 2 (1992): 61-156.

Choi, James J., David Laibson, Brigitte C. Madrian, "Plan Design and 401(k) Savings Outcomes," National Tax Journal, forthcoming, 2004.

Choi, James J., David Laibson, Brigitte C. Madrian, and Andrew Metrick, "Defined Contribution Pensions: Plan Rules, Participant Decisions, and the Path of Least Resistance," in James M. Poterba, ed., Tax Policy and the Economy, Vol. 16 (Cambridge, MA: MIT Press), 2002. 
Choi, James J., David Laibson, Brigitte C. Madrian, and Andrew Metrick, "Optimal Defaults," American Economic Review 93:2 (2003a): 180-185.

Choi, James J., David Laibson, Brigitte C. Madrian, and Andrew Metrick, "Passive Decisions and Potent Defaults," NBER Working Paper No. 9917, 2003 b.

Choi, James J., David Laibson, Brigitte C. Madrian, and Andrew Metrick, "Optimal Defaults and Active Decisions: Theory and Evidence from 401(k) Saving," Harvard University Working Paper, 2003c.

Choi, James J., David Laibson, Brigitte C. Madrian, and Andrew Metrick, "For Better or Worse: Default Effects and 401(k) Savings Behavior," in David A. Wise, ed., Perspectives in the Economics of Aging (Chicago: University of Chicago Press), forthcoming, 2004.

Clark, Robert L. and Sylvester J. Schieber, "Factors Affecting Participation Rates and Contribution Levels in 401(k) Plans," in Living with Defined Contribution Pensions: Remaking Responsibility for Retirement, Olivia S. Mitchell and Sylvester J. Schieber, eds. (Philadelphia: University of Pennsylvania Press), 1998, pp. 69-97.

Coile, Courtney, and Jonathan Gruber, "Social Security and Retirement," NBER Working Paper No. 7830, 2000.

Cunningham, Christopher R., and Gary V. Engelhardt, "Federal Tax Policy, Employer Matching, and 401(k) Saving: Evidence from HRS W-2 Records," National Tax Journal, 55 (2002): 617-645.

Dammon, Robert M., Chester S. Spatt, and Harold H. Zhang, "Optimal Consumption and Investment with Capital Gains Taxes," Review of Financial Studies 14:3 (2001): 583616.

Dammon, Robert M., Chester S. Spatt, and Harold H. Zhang, "Optimal Asset Location and Allocation with Taxable and Tax-Deferred Investing," Journal of Finance 59:3 (2004): 999-1037.

Das, Mitali, Whitney K. Newey, and Francis Vella, "Nonparametric Estimation of Sample Selection Models," Review of Economic Studies 70:1 (2003): 33-63.

Deaton, Angus, "Saving and Liquidity Constraints," Econometrica 59:5 (1991), 12211248.

Diamond, Peter, and Botond Koszegi, "Quasi-hyperbolic Discounting and Retirement," Journal of Public Economics 87 (2003): 1839-1872.

Duflo, Esther, William Gale, Jeffrey Liebman, Peter Orszag, and Emmanuel Saez, "Saving Incentives for Low- and Middle-Income Families: Evidence from a Field 
Experiment with H\&R Block," Quarterly Journal of Economics 121(4): 2006, forthcoming.

Duflo, Esther, and Emmanuel Saez, "Participation and Investment Decisions in a Retirement Plan: The Influence of Colleagues' Choices," Journal of Public Economics 85 (2002): 121-148.

Duflo, Esther, and Emmanuel Saez, "The Role of Information and Social Interactions in Retirement Plan Decisions," Quarterly Journal of Economics 118:3 (2003): 815-842.

Dynan, Karen E., "How Prudent Are Consumers?" Journal of Political Economy 101:6 (1993): 1104-1113.

Elmendorf, Douglas W., "The Effect of Interest-Rate Changes on Household Saving and Consumption: A Survey," Federal Reserve Board Finance and Economics Discussion Series Paper No. 1996-27, 1996.

Employee Benefit Research Institute, Salary Reduction Plans and Individual Saving for Retirement, Issue Brief No. 155 (Washington, DC: Employee Benefit Research Institute), 1994.

Engelhardt, Gary V., "Consumption, Down Payments, and Liquidity Constraints," Journal of Money, Credit, and Banking, 28:2 (May) 1996: 255-271.

Engelhardt, Gary V., "Have 401(k)s Raised Household Saving? Evidence from the Health and Retirement Study," Mimeo., Syracuse University, 2001.

Engelhardt, Gary V., "Pre-Retirement Lump-Sum Pension Distributions and Retirement Income Security: Evidence from the Health and Retirement Study," National Tax Journal 55:4 (December) 2002: 665-686.

Engelhardt, Gary V., "Reasons for Job Change and the Disposition of Pre-Retirement Lump-Sum Pension Distributions" Economics Letters 81:3 (December) 2003a: 333-339.

Engelhardt, Gary V., "Nominal Loss Aversion, Housing Equity Constraints, and Household Mobility: Evidence from the United States," Journal of Urban Economics 53:1 (January) 2003b: 171-195.

Engelhardt, Gary V., "Defined Contribution Pension Plans and the Measurement of Retirement Wealth: Implications for Studies of Pension Knowledge, Saving, and the Timing of Retirement," Mimeo, Syracuse University, 2004.

Engelhardt, Gary V. and Anil Kumar, "Understanding the Impact of Employer Matching on 401(k) Saving," TIAA-CREF Institute Research Dialogue No. 76, 2003. 
Engelhardt, Gary V. and Anil Kumar, "Sorting and 401(k) Employer Matching," Syracuse University Mimeo., 2004a.

Engelhardt, Gary V. and Anil Kumar, "Social Security Personal-Account Participation with Government Matching," Journal of Pension Economics and Finance 4:2 (2005): 155-179.

Engen, Eric M., William G. Gale, and John Karl Scholz, "The Illusory Effects of Saving Incentives on Saving," Journal of Economic Perspectives 10:4 (1996): 113-137.

Even, William E., and David A. Macpherson, "Factors Influencing Employee Participation in 401(k) Plans," Mimeo, Miami University (Ohio), 1996.

Feenberg, Daniel, and Elisabeth Coutts, "An Introduction to the TAXSIM Model," Journal of Policy Analysis and Management 12 (1) (Winter) (1993): 189-194.

General Accounting Office, "401(k) Pension Plans: Loan Provisions Enhance Participation But May Affect Income Security for Some," Report GAO/HEHS-98-5, 1997.

Gomes, Francisco, Alexander Michaelides, Valery Polkovnichenko, "Portfolio Choice and Wealth Accumulation with Taxable and Tax-Deferred Accounts," Mimeo., London Business School, 2004.

Gorman, W.M., "Separable Utility and Aggregation," Econometrica 27:3 (1959): 469481.

Gourinchas, Pierre-Olivier, and Jonathan A. Parker, "Consumption over the Life-Cycle," Econometrica 70:1 (2002): 47-89.

Gruber, Jonathan, "A Tax-Based Estimate of the Elasticity of Intertemporal Substitution,” NBER Working Paper No. 11945, 2006.

Gustman, Alan L., and Thomas L. Steinmeier, "What People Don't Know About Pensions and Social Security: An Analysis Using Linked Data from the Health and Retirement Study,” NBER Working Paper No. 7368, 1999.

Gustman, Alan L., Olivia S. Mitchell, Andrew A. Samwick, and Thomas L. Steinmeier, "Pension and Social Security Wealth in the Health and Retirement Study," in Wealth, Work, and Health: Innovations in Measurement in the Social Sciences, James Smith and Robert Willis, eds. (Ann Arbor: University of Michigan Press) 1999, pp. 150-208.

Hall, Robert, "Intertemporal Substitution in Consumption," Journal of Political Economy 96 (1988): 339-57. 
Hausman, Jerry A., "The Econometrics of Nonlinear Budget Sets," Econometrica (November) 53 (1985), 1255-1282.

Hubbard, R. Glenn, and Jonathan S. Skinner, "Assessing the Effectiveness of Saving Incentives,” Journal of Economic Perspectives 10:4 (1996): 73-90.

Ibbotson Associates, "Stocks, Bonds, Bills and Inflation, 2003 Yearbook (Chicago: Ibbotson Associates), 2003.

Ippolito, Richard A. Pension Plans and Employee Performance, Chicago: University of Chicago Press, 1997.

Jappelli, Tullio, Jorn-Steffen Pischke, and Nicholas S. Souleles, "Testing for Liquidity Constraints in Euler Equations with Complementary Data Sources," Review of Economics and Statistics 80:2 (1998): 251-262.

Johnson, Richard W., Usha Sambamoorthi, and Stephen Crystal. "Pension Wealth at Midlife: Comparing Self-Reports with Provider Data." Review of Income and Wealth 46(1) (2000): 59-83.

Joulfaian, David, and David Richardson, "Who Takes Advantage of Tax-Deferred Savings Programs? Evidence from Federal Income Tax Data," National Tax Journal 54 (2001): 669-688.

Kusko, Andrea, James M. Poterba, and David Wilcox, "Employee Decisions With Respect to 401(k) Plans," in Living with Defined Contribution Pensions: Remaking Responsibility for Retirement, Olivia Mitchell and Sylvester Schieber, eds. (Philadelphia: University of Pennsylvania Press) 1998, pp. 98-112.

Laibson, David, "Golden Eggs and Hyperbolic Discounting," Quarterly Journal of Economics 112 (1997): 443-477.

Laibson, David, Andrea Repetto, and J. Tobacman, "Self-Control and Retirement Savings," Brookings Papers on Economic Activity 1 (1998): 91-196.

MaCurdy, Thomas E., David Green, and Harry Paarsch, "Assessing Empirical Approaches for Analyzing Taxes and Labor Supply," Journal of Human Resources 25 (Summer 1990): 415-90.

Madrian, Brigitte C., and Dennis F. Shea, "The Power of Suggestion: Inertia in 401(k) Participation and Savings Behavior," Quarterly Journal of Economics 116 (2001): 114987.

McDonald, John F., and Robert A. Moffitt, "The Uses of Tobit Analysis," Review of Economics and Statistics 62 (1980): 318-321. 
McGill, Dan M., Kyle N. Brown, John J. Haley, and Sylvester J. Schieber, Fundamentals of Private Pensions, Seventh Edition (Philadelphia: University of Pennsylvania Press), 1996.

Mills, Gregory, William G. Gale, Rhiannon Patterson, and Emil Apostolov, "What Do Individual Development Accounts Do? Evidence from a Controlled Experiment," Mimeo., Brookings Institution, 2006.

Mitchell, Olivia S., "Worker Knowledge of Pension Provisions," Journal of Labor Economics 6 (1988): 21-39.

Mitchell, Olivia, Jan Olson, and Thomas Steinmeier, "Construction of the Earnings and Benefits File (EBF) for Use with the Health and Retirement Survey," HRS/AHEAD Documentation Report No. DR-001, Institute for Social Research, University of Michigan, 1996.

Mitchell, Olivia S., and Stephen P. Utkus, "The Role of Company Stock in Defined Contribution Plans,” NBER Working Paper No. 9250, 2002.

Moffitt, Robert A., "The Econometrics of Piecewise-Linear Budget Constraints," Journal of Business and Economic Statistics 4 (1986): 317-328.

Moffitt, Robert A., "The Econometrics of Kinked Budget Constraints," Journal of Economic Perspectives 4 (1990): 119-139.

Munnell, Alicia H., Annika Sunden, and Catherine Taylor, "What Determines 401(k) Participation and Contributions?” Mimeo., Boston College, 2001.

Newey, Whitney K., "Linear Instrumental Variable Estimation of Limited Dependent Variable Models with Endogenous Explanatory Variables," Journal of Econometrics 32 (1986): 127-141.

Newey, Whitney K., "Specification Tests for Distributional Assumptions in the Tobit Model," Journal of Econometrics 34 (1987a): 125-145.

Newey, Whitney K., "Efficient Estimation of Limited Dependent Variable Models with Endogenous Explanatory Variables,” Journal of Econometrics 36 (1987b): 231-250.

O’Donoghue, Ted, and Matthew Rabin. "Incentives for Procrastinators." Quarterly Journal of Economics 114:3 (1999a): 769-816.

O'Donoghue, Ted, and Matthew Rabin. "Doing It Now or Later." American Economic Review 89:1 (1999b): 103-124.

Papke, Leslie E., "Participation in and Contributions to 401(k) Pension Plans: Evidence from Plan Data," Journal of Human Resources 30:2 (1995): 311-325. 
Papke, Leslie E., Poterba, James M, "Survey Evidence on Employer Match Rates and Employee Saving Behavior in 401(k) Plans”, Economics Letters 49, 313-317, 1995.

Poterba, James M., "Employer Stock and 401(k) Plans," American Economic Review, 93:2 (2003): 398-404.

Poterba, James M., Clemens Sialm, and John B. Shoven, "Asset Location for Retirement Savers," in William G. Gale, John B. Shoven, and Mark J. Warshawsky, eds. Private Pensions and Public Policies. Washington: Brookings Institution, 2001.

Poterba, James M., Steven F. Venti, and David A. Wise, "How Retirement Saving Programs Increase Saving," Journal of Economic Perspectives 10:4 (1996): 91-112.

Powell, James L., "Symmetrically-Trimmed Least Squares Estimation of Tobit Models," Econometrica 54 (1986): 1425-1460.

Rohwedder, Susann, "Empirical Validation of HRS Pension Wealth Measures," Mimeo., Rand Corporation, (2003a).

Rohwedder, Susann, "Measuring Pension Wealth in the HRS: Employer and SelfReports," Mimeo., Rand Corporation, $2003 \mathrm{~b}$.

Shoven, John B., "The Location and Allocation of Assets in Pension and Conventional Savings Accounts," NBER Working Paper No. 7007, 1999.

Shoven, John B., and Clemens Sialm, "Long Run Asset Allocation for Retirement Savings," Journal of Private Portfolio Management 1 (2) (1998): 13-26.

Shoven, John B., and Clemens Sialm, "Asset Location in Tax-Deferred and Conventional Savings Accounts," Journal of Public Economics 88 (2003): 23-38.

Staiger, Douglas, and James H. Stock, "Instrumental Variables Regression with Weak Instruments," Econometrica 65:3 (1997): 557-586.

Starr-McCluer, Martha, and Annika Sunden, "Workers' Knowledge of Their Pension Coverage: A Reevaluation,” Mimeo., Federal Reserve Board of Governors, 1999.

Summers, Lawrence H., "Capital Taxation and Accumulation in a Life Cycle Model," American Economic Review 71 (1981): 533-544.

U.S. Department of Labor, 1993 Private Pension Plan Bulletin (Washington, DC: U.S. Department of Labor), 1995.

U.S. Government Printing Office, 2004 Economic Report of the President (Washington, DC: U.S. Government Printing Office), 2004. 
Vanderhei, Jack, and Craig Copeland, "A Behavioral Model for Predicting Employee Contributions to 401(k) Plans: Preliminary Results," North American Actuarial Journal 5:1 (2001): 80-94.

Vella, Francis, "Simple Tests for Sample Selection Bias in Censored and Discrete Choice Models," Journal of Applied Econometrics 7:4 (1992): 412-421.

Vissing-Jorgensen, Annette, "Limited Asset Market Participation and the Elasticity of Intertemporal Substitution," Journal of Political Economy 110:4 (2002): 825-853.

Ziliak, James, and Thomas Kniesner, "Estimating Life Cycle Labor Supply Tax Effects," Journal of Political Economy 107 (April 1999): 326-359. 


\section{Appendix A}

This appendix lays out the theoretical model in more detail. Additional detail can be provided upon request. This appendix is intended to be supplemental and, given its length, not published.

Previous studies have had two important shortcomings. First, they have not couched their analyses in formal models of intertemporal choice, even though saving involves the substitution of resources across time. This means that previous estimates cannot be interpreted as estimates of life-cycle-consistent determinants of 401(k) saving necessarily, because the empirical specifications may not have been consistent with underlying utility maximization. So, while the existing literature has provided quite informative descriptive analyses, it has said little about how 401(k) saving may respond to prospective changes in employer matching or what the optimal match rate should be to achieve a saving target. Second, with the exception of Choi, Laibson, Madrian, and Metrick (2002) and VanDerhei and Copeland (2001), previous studies have failed to exploit the fact that multiple-match-rate schedules and caps on matching induce kinks in the budget set. ${ }^{20}$

To illustrate the kink, Figure 1 shows budget sets with and without matching in a simple two-period model of consumption (without borrowing) typically used in undergraduate textbooks. Let $C_{1}$ and $C_{2}$ be consumption in period 1 when working and period 2 when retired, respectively, and $y_{1}^{l}$ be first-period gross labor earnings. For simplicity, assume federal marginal income tax rates, $\theta_{1}^{F}$, in the first period, and $\theta_{2}^{F}$, in the second period, and no labor earnings in the second period. Let $W^{S S}$ be the present value of traditional Social Security wealth, $r$ be the gross return, and assume that Social Security is not taxed when retired. Assume that the 401(k) is the only form of voluntary saving, and contributions, $Q^{V O L}$, measured in dollars from right to left on the horizontal axis, are matched at a fixed rate, $m^{V O L}$, up to a cap, $Q^{\text {match }}$, based on the amount of the voluntary contributions. The upper limit on voluntary contributions is $Q^{\max }$. The budget constraint without matching is $\overline{a b c d}$. With matching, it is $\overline{a b k h i}$, and from 0 to $Q^{\text {match }}$ (reading right to left, beginning at point $a$ ), the slope is

${ }^{20}$ Both of these studies examined the impact of match rates and caps on $401(\mathrm{k})$ participation and contributions, but from rather different perspectives than in this paper. Specifically, Choi, Laibson, Madrian, and Metrick (2002) examined large samples of employee administrative data from two firms, one that introduced a match of 25 percent up to 4 percent of pay and another that held the match rate constant but increased the match cap. Their reduced-form estimates were not inconsistent with a relatively moderate substitution effect and a very small income effect. Copeland and VanDerhei (2001) estimated the impact of match rates and caps using a reduced-form sequential-response regression model for 137 matching formulas and a very large sample of participants, in which a separate equation was estimated for each match rate the participant faced. They, too, found evidence that matching raised participation and contributions. Probably the biggest difference between these studies and the current paper is that the analysis below is based on a life-cycle-consistent empirical specification, constructs the household's budget set (rather than the employee), and incorporates virtual income into the estimation. A companion paper, Engelhardt and Kumar (2003), provided a further discussion of the previous literature. 
$-\left(1-\theta_{2}^{F}\right)\left(1+m^{V}\right)(1+r) /\left(1-\theta_{1}^{F}\right)$, from $Q^{\text {match }}$ to $Q^{\max }, \quad$ the slope is $-\left(1-\theta_{2}^{F}\right)(1+r) /\left(1-\theta_{1}^{F}\right)$, and beyond $Q^{\max }$, the slope is zero. At the match cap, $Q^{\text {match }}$, there is a kink point, $k$, at which the match is exhausted.

The introduction of the employer match with a cap has differential effects depending upon the location on the budget set. For low levels of contributions, the budget set rotates outward, and there are opposing income and substitution effects, but for higher levels of contributions, the budget set shifts out in parallel, and there is only an income effect, for which contributions fall with the imposition of the match. Furthermore, once the match cap is in place, changes in the match rate, $m^{V}$, may not induce changes in contributions if individuals are bunched at the kink point, $k$, and standard income and substitution effects are not well defined. Instead, income and substitution effects on each budget segment are defined by the slopes given above and the virtual incomes shown in the figure, $y^{v_{1}}$ and $y^{v_{2}}$, respectively.

By specifying a detailed theoretical framework, this paper represents a stark departure from the previous literature. There were eight criteria that guided the model detailed below. First, it should incorporate non-linear budget sets explicitly. In particular, the budget sets individuals actually face are substantially more complicated than the ones depicted in Figure 1, because they may have multiple kinks due to variablerate matches, and there may be multiple kinks because there are multiple marginal tax rates, and contributions are tax-deductible, so that making a contribution may change the marginal tax rate. Surprisingly, none of the previous studies even have accounted for the effect of taxation on 401(k) saving. Second and third, respectively, the model should allow for goods other than consumption, such as leisure, that enter utility-because a change in the match rate may induce intratemporal substitution across goods - and for uncertain lifetimes and bequests, facets that are important to individuals of the ages found in the HRS. Fourth, the model should allow for wealth accumulation in many forms, because 401(k) plan participants can save through means that differ from $401(\mathrm{k}) \mathrm{s}$ in terms of tax treatment and liquidity, especially those that have been identified by previous studies as potential channels for 401(k)-saving offsets: taxable and IRA wealth (Poterba, Venti, and Wise, 1996; Hubbard and Skinner, 1996; Engen, Gale, and Scholz, 1996); Social Security, defined-benefit and non-401(k) defined-contribution pensions (Gale, 1998; Engelhardt, 2001); and mortgage debt (Engen and Gale, 1998). ${ }^{21}$ Fifth, when formulating the household budget constraint, the model should specify in detail the tax treatment of $401(\mathrm{k})$ and IRA contributions, respectively, IRA withdrawals, and the interrelationship between employer matching, 401(k) plan characteristics, and the price of leisure. This is a critical part of the analysis because the non-linear-budget-set estimation requires that non-linearities be well specified, and it is something that has been omitted from previous reduced-form studies. Sixth, it should allow for an uncertain rate of return and liquidity constraints, two central features of models of consumption in the literature. Seventh, in addition to the optimal asset allocation decision across the different forms of

\footnotetext{
${ }^{21}$ Technically, 401(k)s are defined-contribution plans under federal law, but a distinction will be made throughout this analysis between 401(k)s and all other DC plans, where the latter category will be referred to as "non-401(k)" DC plans and includes plans such as money-purchase, ESOP, target benefit, and profitsharing plans. The exact type of plan is indicated in the pension plan data used in the analysis.
} 
wealth, the model should follow a series of papers, including Shoven (1999), Shoven and Sialm (1998, 2003), Poterba, Sialm, and Shoven, (2001), Dammon, Spatt, and Zhang (2004), and Gomes, Michaelides, and Polkovnichenko (2004), among others, and allow for an optimal asset location decision, whereby the consumer must decide which assets to hold in taxable and tax-deferred forms. Finally, it should be tractable enough to be used directly to formulate an econometric model of 401(k) saving that is consistent with intertemporal optimization.

Formally, intratemporal direct utility, $U(C, l ; \mathbf{z})$, is derived from leisure, $l$, with an associated price, $p^{l}$, consumption of a composite good, $C$, with an associated price, $p^{c}$, and a vector of demographics, $\mathbf{z}$. Intratemporal utility is weakly separable, and intertemporal utility is additively separable. The consumer faces a per period probability of survival of $\rho$, with period $\mathrm{T}$ being the known maximum length of life. With probability $1-\rho$, the consumer dies and receives the terminal payoff $\Phi\left(W^{T}\right)$, the utility of bequests, which is a function of total wealth, $W^{T}$. The lifetime is composed of two parts: from period $\mathrm{N}$ to $\mathrm{T}$, the consumer is retired and no hours of labor are supplied to the market, so leisure equals the time endowment, $L^{l}$; from period 0 to $\mathrm{N}-1$, the consumer works, and the timing of retirement in period $\mathrm{N}$ is endogenous. Total wealth is accumulated in seven forms when working: wealth from IRAs, $W^{I R A}$; wealth from 401(k)s, $W^{401 k}$; wealth from non-401(k) defined-contribution pension plans, $W^{D C}$; wealth from defined-benefit pension plans, $W^{D B}$; Social Security wealth, $W^{S S}$; housing equity, $W^{H}$; and taxable wealth, $W^{T A}$. Each period when working, the consumer chooses consumption, leisure, voluntary 401(k) contributions, $Q^{V O L}$, IRA contributions, $Q^{I R A C}$, IRA withdrawals, $Q^{I R A W}$, and the housing loan-to-value ratio, $\phi$, (discussed below). Each period when retired, the consumer chooses consumption, IRA contributions, IRA withdrawals, the housing loan-to-value ratio, and receives eligible pension and Social Security benefits. Because 401(k) contributions can be made only while employed, the remaining description of the model focuses on the period when working, in the interest of exposition. ${ }^{22}$

The literature on optimal asset allocation and location to taxable and tax-deferred accounts has argued that, because capital gains are taxed more lightly than interest income in the United States, the consumer has the incentive to hold relatively heavily taxed bonds in tax-deferred accounts and relatively lightly taxed stocks in taxable accounts. ${ }^{23}$ The model allows the consumer to choose the optimal allocation of IRA, DC, 401(k), and taxable wealth between stocks and bonds, in addition to the choice variables described above. Specifically, the model follows this literature and collapses IRA, DC, and $401(\mathrm{k})$ wealth into a single group, called retirement-account wealth, $W^{R A} \equiv W^{I R A}+W^{D C}+W^{401 k}$, when formulating the intertemporal budget constraint.

\footnotetext{
${ }^{22}$ Details of the complete model are available upon request.

${ }^{23}$ The obvious exception to this result is that tax-exempt municipal bonds should be held in the taxable account.
} 
This is done for three reasons. First, IRAs, DC plans, and 401(k)s are all tax-deferred forms of saving, in that contributions are not taxed when made, they allow for inside build-up at the pre-tax rate of return, and qualified withdrawals are taxed as ordinary income at the time of withdrawal, so, in principle, there is little, if any, difference between vehicles. ${ }^{24}$ Second, federal law allows an employee to roll a DC or 401(k) account balance over to an IRA upon job severance, so, in practice, assets that were once accumulated in an employer-provided pension may appear on the household balance sheet as IRA wealth (Engelhardt, 2002 and 2003a). ${ }^{25}$ Third, this assumption helps keep the model tractable. Therefore, total wealth is defined as

$$
W^{T} \equiv W^{R A}+W^{T A}+W^{D B}+W^{S S}+W^{H} .
$$

Let $s^{h}$ be the beginning-of-period share of total wealth in asset type $h$, $h=R A, T A, D B, S S, H$.

Defined-benefit pension and Social Security wealth evolve, respectively, as

$$
W_{t+1}^{D B}=\left(1+\alpha_{t}^{D B}\right) s_{t}^{D B} W_{t}^{T},
$$

and

$$
W_{t+1}^{S S}=\left(1+\alpha_{t}^{S S}\right) s_{t}^{S S} W_{t}^{T} .
$$

For defined benefit plans, the accrual, $\alpha^{D B}$, is determined by a plan formula that is usually a complicated function of age, earnings, and years of service. The Social Security accrual, $\alpha^{S S}$, is determined by benefit formulas in the federal law. The model assumes that DB and Social Security wealth are illiquid until retirement and cannot be used as collateral. ${ }^{26}$

Following Gomes, Michaelides, and Polkovnichenko (2004), retirement-account and taxable wealth can be invested either in bonds, with riskless pre-tax return $r^{B}$, or in stocks, with a risky pre-tax return

$$
\widetilde{r}_{t}^{S}=\frac{1+\widetilde{g}_{t}+d}{1+\pi}-1,
$$

where $\pi$ is the constant inflation rate, $d$ is the constant nominal dividend yield, and $\widetilde{g}$ is the stochastic nominal capital gain earned from the beginning of period $t$ to the beginning of period $t+1 .{ }^{27}$ Throughout the analysis, a return with a tilde will indicate an

24 There is a clear distinction in the model between deductible and non-deductible IRA contributions. Related to this, note that Roth IRAs were not available in 1991, the calendar year of the empirical analysis below.

${ }^{25}$ There is very clear evidence of these rollovers in the HRS data used below. In particular, there are individuals who have IRA wealth that is substantially higher than what they would have accumulated had they made limit contributions since 1981, when IRAs became legally widely available, at plausible rates of return. Theses individuals also self-reported having rolled pension assets over to an IRA.

${ }^{26}$ Federal law prevents the use of Social Security or pension assets as collateral for loans, so that the illiquidity of these assets is a standard assumption in the literature.

${ }^{27}$ With respect to the empirical analysis described below, the HRS pension data tell whether employer stock was an investment option both for the employee voluntary contributions and the employer match, but only for plans that allowed individual-directed investment. Unfortunately, for plans that did not allow for individual-directed investment, the HRS did not electronically code this information off of the SPDs, so that it is not known whether employee and employer contributions were required to be invested in 
ex ante uncertain return, whereas one without will indicate either an ex post realization or a certain return. Let $R^{R A}$ be the weighted-average return on wealth in retirement accounts,

$$
R_{t}^{R A} \equiv\left(1-\vartheta_{t}^{R A}\right)\left(1+r_{t}^{B}\right)+\vartheta_{t}^{R A}\left(1+\widetilde{r}_{t}^{S}\right),
$$

where $\vartheta^{R A}$ is the share of retirement-account wealth invested in stocks. Then retirementaccount wealth evolves as

$$
W_{t+1}^{R A}=R_{t}^{R A}\left[s_{t}^{R A} W_{t}^{T}+F_{t}+Q_{t}^{V O L}+M_{t}^{V O L}+Q_{t}^{M A N}+M_{t}^{M A N}+Q_{t}^{I R A C}-Q_{t}^{I R A W}\right] .
$$

Some employers mandate 401(k) contributions, shown as $Q^{M A N}$ in (A.6), and the employer may match those mandatory contributions (Cunningham and Engelhardt, 2002). In (A.6), $M^{M A N}$ is the employer's matching contribution in dollars on the employee's mandatory contribution, and $M^{V O L}$ is the employer's matching contribution in dollars on the employee's voluntary contribution, $Q^{V O L}$. The matching functions are

$$
M_{t}^{V O L}=M^{V O L}\left(Q_{t}^{V O L}, y_{t}^{l}, \mathbf{m}_{t}^{V O L}\right)
$$

and

$$
M_{t}^{M A N}=M^{M A N}\left(Q_{t}^{M A N}, y_{t}^{l}, \mathbf{m}_{t}^{M A N}\right),
$$

respectively, and are twice continuously differentiable; $y^{l}$ is labor earnings; $\mathbf{m}^{V O L}$ and $\mathbf{m}^{\text {MAN }}$ are vectors of plan-specified match rates for voluntary and required contributions, respectively. In (A.6), $F$ is the employer's non-matching contribution for the plan. ${ }^{28}$ The model assumes that DC and 401(k) wealth are illiquid until retirement and cannot be used as collateral, but allows IRA withdrawals when working (discussed below). ${ }^{29}$

Housing equity is defined as $W^{H} \equiv P-D$. Housing value, $P$, evolves as

$$
P_{t+1}=\left(1+r_{t}^{P}\right) P_{t},
$$

where $r^{P}$ is the return on housing value. Mortgage debt is $D=\phi P$, where $\phi$ is the loanto-value (LTV) ratio, and $D$ evolves as

$$
D_{t+1}=\left(1+r_{t}^{D}\right) D_{t},
$$

where $r^{D}$ is the real mortgage-interest rate,

employer stock. Therefore, it is not possible to model and estimate the impact of employer stock on contribution behavior here specifically. Poterba (2003), Brown, Liang, and Weisbenner (2004), and Mitchell and Utkus (2002) have studied various aspects of investment in company stock.

${ }^{28}$ These would be contributions the employer makes on a periodic basis, as specified in the SPD, but are not related to any voluntary or mandatory contributions by the employee: for example, those defined as a percentage of pay in a money purchase plan or as a function of some measure of firm performance in a profit-sharing plan.

${ }^{29}$ There are 401(k) plans that allow hardship withdrawals and/or borrowing against plan balances when working that provide some liquidity to $401(\mathrm{k})$ saving. However, even though the SPD for each plan indicates whether, the extent to which, and the terms under which, hardship withdrawals and borrowing can occur, these features were not electronically coded by the HRS. Therefore, liquidity through hardship withdrawals and borrowing could not be incorporated as choice variables directly into the intertemporal budget constraint. Instead, the existence of these liquidity channels, for plans that offer them, are controlled for directly as explanatory variables in the empirical analysis. 


$$
r_{t}^{D} \equiv \frac{1+n_{t}^{D}}{1+\pi}-1
$$

and $n^{D}$ is the nominal mortgage-interest rate. Equations (A.9) and (A.10) can be used to write housing equity in period $t+1$ in terms of the LTV:

$$
W_{t+1}^{H}=\left(1+r_{t}^{P}\right) \frac{1}{1-\phi_{t}} s_{t}^{H} W_{t}^{T}-\left(1+r_{t}^{D}\right) \frac{\phi_{t}}{1-\phi_{t}} s_{t}^{H} W_{t}^{T} .
$$

In the model, the real mortgage-interest-payment portion on the right-hand side of (A.12), defined as $B \equiv r^{D}(\phi / 1-\phi) s^{H} W^{T}$, is required to be paid out of cash on hand and appears in (14) below, so that the evolution equation for housing equity reduces to

$$
W_{t+1}^{H}=\frac{\left(1+r_{t}^{P}\right)-\phi_{t}}{1-\phi_{t}} s_{t}^{H} W_{t}^{T} .
$$

Finally, the equation of evolution for taxable wealth is

$W_{t+1}^{T A}=R_{t}^{T A}\left[s_{t}^{T A} W_{t}^{T}+w_{t}\left(L^{l}-l_{t}\right)+y_{t}^{o}-p_{t}^{c} C_{t}-Q_{t}^{V O L}-Q_{t}^{I R A C}+Q_{t}^{I R A W}-B_{t}-T_{t}\right]$,

(A.14)

where $R^{T A}$ is the return on taxable wealth,

$$
R_{t}^{T A} \equiv\left(1-\vartheta_{t}^{T A}\right)\left(1+r_{t}^{B}\right)+\vartheta_{t}^{T A}\left(1+\widetilde{r}_{t}^{S}\right),
$$

$\vartheta^{T A}$ is the share of taxable wealth invested in stocks, $y^{o}$ is other income, $w$ is the gross hourly wage rate, $w\left(L^{l}-l\right) \equiv y^{l}$ is labor earnings, and $B$ is the real mortgage-interest payment. $^{30}$ In (A.14), $T$ is the sum of income and payroll tax liability. It is a twice continuously differentiable function,

$$
T_{t}=f^{T}\left(\boldsymbol{\theta}_{t}^{F}, \boldsymbol{\theta}_{t}^{P}, \boldsymbol{\theta}_{t}^{E} ; I_{t}^{F}, \min \left(y_{t}^{l}, \mathbf{L}_{t}^{P}\right), D_{t}^{A g e 59-1 / 2} \cdot Q_{t}^{I R A W}\right),
$$

of a vector of statutory marginal income tax rates, $\boldsymbol{\theta}^{F}$, Social Security and Medicare payroll tax rates, $\boldsymbol{\theta}^{P}$, and the penalty-tax rate, $\boldsymbol{\theta}^{E}$, on early, non-qualified IRA withdrawals, which are defined by $D^{\text {Age59-1/2}} \cdot Q^{I R A W}$, where $D^{\text {Age59-1/2 }}$ is a dummy variable that is one if the individual is under age $59 \frac{1}{2}$ and is zero otherwise. ${ }^{31}$ Federal taxable income is

$$
I_{t}^{F}=\left\{\left(y_{t}^{l}-Q_{t}^{V O L}-Q_{t}^{M A N}\right)+\lambda_{t} Q_{t}^{I R A W}+K_{t}-\zeta_{t} Q_{t}^{I R A C}\right\}-G_{t} .
$$

The term in parentheses within the braces in (A.17) is income for federal tax purposes reported on Form W-2, the term in braces is adjusted gross income (AGI), and the term $G$ represents the sum of personal exemptions and deductions, and includes deductible

30 Because the mean age in the HRS sample below is 55, and Carroll (1992) and Gourinchas and Parker (2002), among others, have estimated that most lifetime income uncertainty has been resolved by this age, at which point households have transitioned from buffer-stock to life-cycle savers, income uncertainty likely was not central to the households under study and is not included in the model, but would be an important consideration in comparing the empirical results below to those based on a younger sample. However, note that, as stressed by MaCurdy and Blundell (1999), the two-stage budgeting empirical approach adopted below explicitly can handle multiple forms of uncertainty, including, for example, wage uncertainty, and, therefore, in principle, this assumption does not compromise the basic framework underlying the empirical specification.

31 For simplicity in exposition, we have suppressed notation for state income taxes. However, we include them in the empirical analysis below. Engelhardt (2002) discussed lump-sum distributions in detail. 
nominal mortgage interest for homeowners. ${ }^{32}$ The term $K$ is taxable capital income and is the sum of taxable interest income from bonds and taxable dividend and realized capital-gain income from stocks. ${ }^{33}$ The factor $\lambda$ is the fraction of IRA withdrawals that is federally taxable and depends on age and whether the withdrawal was qualified or not. $^{34}$ The factor $\zeta$ is the fraction of IRA contributions that is federally tax-deductible. It depends on adjusted gross income (AGI), and itself is a function of 401(k) contributions and IRA withdrawals, because 401(k) contributions are excluded from AGI and the taxable portion of withdrawals enters AGI. ${ }^{35} \mathbf{L}^{P}$ is a vector of covered-earnings caps for payroll taxes.

Equations (A.2), (A.3), (A.6), (A.13), and (A.14) sum to yield the intertemporal budget constraint that determines $W_{t+1}^{T}$. In addition, there are five other constraints on behavior. First, following Deaton (1991), there is a liquidity constraint,

$$
W_{t}^{T A} \geq 0
$$

which means that total per period full expenditure (also referred to as "full income" in the two-stage budgeting literature), $y$, defined as

$$
y_{t} \equiv p_{t}^{c} C_{t}+w_{t} l_{t}+B_{t},
$$

must be less than or equal to total net cash on hand, $X$, defined as beginning-of-period liquid taxable wealth and other income on hand, plus the market value of the leisure endowment, less the tax liability, plus any IRA wealth made liquid through a withdrawal, less any tax-deferred saving:

$$
X_{t} \equiv W_{t}^{T A}+y_{t}^{o}+w_{t} L^{l}-T_{t}-Q_{t}^{V O L}-Q_{t}^{I R A C}+Q_{t}^{I R A W} .
$$

Let $\mu_{t}$ be the associated Kuhn-Tucker multiplier. This formalizes the assumption that 401(k), defined-contribution, defined-benefit pension, and Social Security assets are illiquid prior to retirement. Second, although IRA withdrawals help to loosen the

32 In the model, the housing service flow enters the composite commodity, $C$, and its rental cost for renters and the implicit rental cost for homeowners is subsumed into the price index, $p^{c}$.

33 Dammon, Spatt, and Zhang $(2001,2004)$ have provided detailed models of consumption and investment, with and without tax-deferred assets, which specified detailed tax treatment of realized and unrealized capital gains.

34 Engelhardt (2002) outlined and examined empirically in the HRS the federal tax treatment of nonqualified pre-retirement withdrawals from 401(k) and IRA plans. Federal law allows penalty-free withdrawals from IRAs at age 591/2, at which point IRA assets become liquid; prior to 591/2, tax-qualified withdrawals are allowed for a very limited number of reasons, and non-qualified withdrawals are assessed a penalty tax. The HRS surveyed individuals who were 51-61 in 1992, so some in the sample analyzed below are eligible for qualified withdrawals.

35 Prior to the Tax Reform Act of 1986 (TRA86), IRA contributions were fully tax-deductible up to the limit of $\$ 2,000$ for single individuals and $\$ 2,250$ for married couples. TRA86 limited the deductibility of contributions. For single individuals, contributions remained fully deductible if adjusted gross income was less than $\$ 25,000$, were linearly phased out for incomes between $\$ 25,000$ and $\$ 35,000$, and not deductible for incomes above $\$ 35,000$. For married couples, contributions remained fully deductible if adjusted gross income was less than $\$ 40,000$, were linearly phased out for incomes between $\$ 40,000$ and $\$ 50,000$, and not deductible for incomes above $\$ 50,000$. Therefore, $\zeta$ varies according to a non-linear interaction of income, and marital status. 
liquidity constraint by increasing total net cash on hand in (A.20), there are the following minimum and maximum constraints on withdrawals, with multipliers in square brackets:

$$
\begin{array}{lll}
Q_{t}^{I R A W} \geq D_{t}^{\text {Age } 70-1 / 2} \cdot \frac{W_{t}^{I R A}}{h_{t}}, & & {\left[\varphi_{t}^{0}\right]} \\
Q_{t}^{I R A W} \leq W_{t}^{I R A} . & & {\left[\varphi_{t}^{L}\right]}
\end{array}
$$

In (A.21), $D^{\text {Age } 70-1 / 2}$ is a dummy variable that is one if the individual is age $701 / 2$ or older and is zero otherwise, and $h$ is the individual's life expectancy. Thus, if under age $701 / 2$, the withdrawal must be greater than or equal to zero, and, if age $70 \frac{1}{2}$ or older, the withdrawal must satisfy the minimum-distribution requirements under federal law that are a function of life expectancy. Equation (22) states that the withdrawal cannot exceed the beginning-of-period IRA wealth. ${ }^{36}$ Third, the minimum- and maximum-contribution constraints on $401(\mathrm{k}) \mathrm{s}$ and IRAs with multipliers in square brackets, respectively, are

$$
\begin{array}{ll}
Q_{t}^{V O L} \geq 0, & {\left[\eta_{t}^{0}\right]} \\
Q_{t}^{V O L} \leq L_{t}^{V O L}, & {\left[\eta_{t}^{L}\right]} \\
Q_{t}^{I R A} \geq 0, & {\left[v_{t}^{0}\right]}
\end{array}
$$

and

$$
Q_{t}^{I R A} \leq L_{t}^{I R A} . \quad\left[v_{t}^{L}\right]
$$

The terms $L_{t}^{V O L}$ and $L_{t}^{I R A}$ are the upper limits on $401(\mathrm{k})$ and IRA contributions, respectively. $\quad L_{t}^{I R A}$ is governed by federal law and depends on marital status and pension coverage. $^{37} L_{t}^{V O L}$ is governed by the employer's plan, but may not exceed the federal statutory maximum. ${ }^{38}$ Fourth, the loan-to-value ratio must lie in the unit interval for homeowners, but there may be a minimum home-equity constraint-such as a downpayment constraint (Engelhardt, 1996 and 2003b; Campbell and Cocco, 2003)-that further constrains the LTV to be below some exogenous threshold, $\bar{\phi}$. Formally, these constraints are

$$
\begin{array}{ll}
\phi_{t} \geq 0, & {\left[\varsigma_{t}^{0}\right]} \\
\phi_{t} \leq \bar{\phi}_{t}, & {\left[\varsigma_{t}^{L}\right]}
\end{array}
$$

where $\bar{\phi} \leq 1$. Finally, there are constraints on the shares of retirement-account and taxable assets allocated to stocks:

$$
\begin{aligned}
& \vartheta_{t}^{R A} \geq 0, \\
& \text { [ } \left.\varpi_{t}^{0}\right] \\
& \vartheta_{t}^{R A} \leq 1 \text {, } \\
& {\left[\varpi_{t}^{L}\right]} \\
& \vartheta_{t}^{T A} \geq 0 \text {, }
\end{aligned}
$$

and

\footnotetext{
${ }^{36}$ Note that the penalty tax on non-qualified withdrawals (e.g., those prior to age $59^{1 / 2}$ ) is accounted for in the taxes-paid function in (A.16).

${ }^{37}$ These limits apply to the sum of deductible and non-deductible IRA contributions.

${ }^{38}$ Leisure is not modeled as bounded by zero and the leisure endowment because 401(k) matching contributions are available only to those who work.
} 


$$
\vartheta_{t}^{T A} \leq 1
$$

$\left[\chi_{t}^{L}\right]$

To summarize, the only forms of "active" saving when working are through contributions to 401(k), IRA, or taxable assets; adjustments can be made to the mortgagedebt position as well. ${ }^{39}$ However, the primary technology for smoothing resources across periods when working is through taxable-asset saving, because 401(k) saving is illiquid; IRA contributions are not necessarily illiquid because of the availability of withdrawals, but IRA withdrawals may incur a tax penalty; traditional pensions and Social Security are illiquid; and the extent of mortgage borrowing is limited. This means that the consumer's optimization does not imply automatically that all active saving be allocated first to the tax-preferred asset with the highest net return, because, in the face of uncertainty, the consumer must balance the desire for a high return with the need for liquidity.

Consumption and hours are not fully observed in the HRS, so that, from the perspective of the empirical analysis, it is desirable to work with the indirect, rather than the direct, utility function. Specifically, let $V(\mathbf{p}, y ; \mathbf{z})$ be the intratemporal indirect utility function. It takes as arguments the vector of prices of leisure and consumption, $\mathbf{p}$, full income, $y$, given in (A.19), and the vector of demographics, $\mathbf{z}$. Following Browning, Deaton, and Irish (1985), let $\mathscr{V}_{t}^{*}\left(W_{t}^{T}\right)$ be the sum of current and future expected utility based on total wealth in period $t$. The individual makes all decisions at the beginning of the period, based on the information set, $\Omega_{t}$, after which, $r^{s}$ is realized. $E$ is the expectations operator conditional on the information set, and $\beta$ is the discount rate. Then for any time $t, t<\mathrm{N}$, the dynamic optimization problem can be written as

$$
\begin{aligned}
\vartheta_{t}^{*}\left(W_{t}^{T}\right)=\max _{\{\mathbf{c}\}} & \left\{V\left(\mathbf{p}_{t}, y_{t} ; \mathbf{z}\right)+E_{t}\left[\rho_{t} \beta V_{t+1}^{*}\left(W_{t+1}^{T}\right)+\left(1-\rho_{t}\right) \beta \Phi\left(W_{t+1}^{T}\right)\right]+\mu_{t}\left(X_{t}-y_{t}\right)\right. \\
& +\varsigma_{t}^{L}\left(\bar{\phi}_{t}-\phi_{t}\right)+\varsigma_{t}^{0}\left(\phi_{t}-0\right)+\eta_{t}^{L}\left(L_{t}^{V O L}-Q_{t}^{V O L}\right)+\eta_{t}^{0}\left(Q_{t}^{V O L}-0\right) \\
& +v_{t}^{L}\left(L_{t}^{I R A C}-Q_{t}^{I R A C}\right)+v_{t}^{0}\left(Q_{t}^{I R A C}-0\right)+\varphi_{t}^{L}\left(W_{t}^{I R A}-Q_{t}^{I R A W}\right) \\
& +\varphi_{t}^{0}\left(Q_{t}^{I R A W}-D_{t}^{A g e 70-1 / 2} \cdot\left(W_{t}^{I R A} / h_{t}\right)\right) \\
& \left.+\varpi_{t}^{L}\left(1-\vartheta_{t}^{R A}\right)+\varpi_{t}^{0}\left(\vartheta_{t}^{R A}-0\right)+\chi_{t}^{L}\left(1-\vartheta_{t}^{T A}\right)+\chi_{t}^{0}\left(\vartheta_{t}^{T A}-0\right)\right\},
\end{aligned}
$$

where c contains the choice variables: $y_{t}, Q_{t}^{V O L}, Q_{t}^{I R A C}, Q_{t}^{I R A W}, \phi_{t}, \vartheta_{t}^{R A}, \vartheta_{t}^{T A}$; and there is a two-stage budgeting interpretation. ${ }^{40}$ In the first-stage, the individual chooses full income, dis-saving through IRA withdrawals, the mortgage-debt position, and the portfolio allocations to stock of retirement-account and taxable wealth, and must allocate total "active" saving to three asset categories-401(k), IRA, and taxable wealth-to maximize the expected present discounted value of lifetime indirect utility. Note that the

\footnotetext{
${ }^{39}$ Amronin, Huang, and Sialm (2006) examine the tradeoff between prepaying mortgages and saving through tax-deferred assets in detail.

${ }^{40}$ The necessary condition for two-stage budgeting is that utility be weakly separable (Gorman, 1959). The model assumes strongly intertemporally and weakly intratemporally separable preferences, so that a twostage budgeting interpretation is valid. The choices of $401(\mathrm{k})$ contributions and portfolio shares do not apply when not working, where with regard to the latter it is assumed for simplicity that pension wealth is annuitized at retirement.
} 
choice variable for taxable-asset saving is made redundant by the intertemporal budget constraint and does not appear explicitly in $\mathbf{c}$. In the second stage, optimal full income, $y^{*}$, in each period is allocated statically between the goods that enter direct utility: consumption and leisure.

The first-order conditions when working for 401(k) contributions, IRA contributions, and full income can be expressed as

$$
\begin{aligned}
\eta_{t}^{L}-\eta_{t}^{0} & =E_{t}\left\{\left[R_{t}^{R A}\left(1+M_{Q_{t}^{401 k}}^{V}\right)-R_{t}^{T A}\left(1-T_{I t}\left(1-\zeta_{y^{l}} Q_{t}^{I R A}\right)\right)\right] \cdot\left[\rho_{t} \beta \vartheta_{W_{t+1}^{T}}^{*}+\left(1-\rho_{t}\right) \beta \Phi_{W_{t+1}^{T}}^{T}\right]\right\} \\
& -\mu_{t}\left(1-T_{I t}\left(1-\zeta_{y^{l} t} Q_{t}^{I R A}\right)\right), \\
v_{t}^{L}-v_{t}^{0}= & E_{t}\left\{\left[R_{t}^{R A}-R_{t}^{T A}\left(1-T_{I t} \zeta_{t}\right)\right] \cdot\left[\rho_{t} \beta \vartheta_{W_{t+1}^{T}}^{*}+\left(1-\rho_{t}\right) \beta \Phi_{W_{t+1}^{T}}\right]\right\}-\mu_{t}\left(1-T_{I t} \zeta_{t}\right),
\end{aligned}
$$

and

$$
V_{y}\left(\mathbf{p}_{t}, y_{t} ; \mathbf{z}\right)=E_{t}\left\{R_{t}^{T A}\left[\rho_{t} \beta \vartheta_{W_{t+1}^{T}}^{*}+\left(1-\rho_{t}\right) \beta \Phi_{W_{t+1}^{T}}^{T}\right]\right\}+\mu_{t},
$$

respectively. Note that subscripts indicate a partial derivative (other than $t$, which denotes time): for example, $T_{I}$ is simply the marginal tax rate; $M_{Q^{401 k}}^{V}$ is the marginal employer match rate for an additional dollar of $401(\mathrm{k})$ contribution; $\zeta_{y^{\prime}}$ is the change in the fraction of an IRA contribution that is deductible for an additional dollar of AGI; and $V_{y}$ is the marginal utility of full income. ${ }^{41}$

${ }^{41}$ The first-order conditions for the other choice variables are available upon request and are not shown here simply in the interest of exposition. 


\section{Appendix B}

This appendix describes the construction of and gives background on the analysis dataset. Additional detail can be provided upon request.

The sample consists of 1,042 individuals from wave 1 of the HRS who were employed in 1991, eligible for a 401(k), whose employer provided a SPD for the plan, and who had linked administrative W-2 and Social Security earnings data. The restricted-access employer-provided SPDs are distributed as the HRS Wave 1 Pension Plan Detail Data Set (Gustman, Mitchell, Samwick, and Steinmeier, 1999). This dataset contains plan type, eligibility rules, benefit formulae, employer contribution and matching formulae, early and normal retirement dates, and other information described in the SPD, but not any information for individual employees. The W-2 data are distributed as the HRS Wages and Self-Employment Income in Covered and Non-Covered Jobs dataset (Mitchell, Olson, and Steinmeier, 1996). The dataset is a cross-section for 1991 because even though there are earnings and deferral data prior to 1991, there are no data on other income and wealth needed to construct full income prior to 1991 in the HRS. Some of the individuals in the sample worked in 1991 but were retired at the time of the first interview in 1992. Exclusion of these individuals had no impact on the estimation results.

There are four types of employer matching: fixed-rate, discretionary, profitsharing, and variable-rate matching. Engelhardt and Kumar (2003) discussed these in detail. Because the extent of matching is not always known in advance to employees making deferral decisions in profit-sharing and discretionary plans, these plans were not included in our sample. The SPDs were used to construct the complete schedule of employer matching contributions for each individual in our sample and applied all relevant restrictions on plan eligibility in the SPD, including those due to tenure, hours, earnings, age, and vesting of the employer matching contributions.

Because workers' budget sets can have multiple kinks and, therefore, multiple points of non-differentiability, from changes in match and marginal tax rates, a smooth, differentiable budget set around all kink points was constructed, following the methodology of MaCurdy, Green, and Paarsch (1990). Specifically, kernel regression of the implicit subsidy from employer matching and tax deductibility on the set of potential contributions from 0 to $\$ 9500$ (the federal maximum contribution in 1991) by $\$ 50$ increments was used to smooth the budget set, using the Gaussian kernel, $K(z)=(1 / \sqrt{2 \pi}) e^{-z^{2} / 2}$, with bandwidth chosen by Silverman's rule of thumb, $h=0.9 m / n^{1 / 5}$, where $m=\min \left(\sqrt{\operatorname{var}_{x}}, i q r_{x} / 1.349\right)$ and $i q r_{x}$ is the inter-quartile range. A smooth marginal implicit subsidy function was constructed from the kernel-regression estimates. The respondent-reported income in wave 1 of the HRS referred to behavior in calendar year 1991; hence, $\Delta A$ was formed by using taxable wealth in 1992 taken from 
wave 1, taxable wealth in 1991, which was capitalized from 1991 capital income, a technique is commonly used in the literature, and $R^{T A}$ constructed from a weightedaverage gross return based on returns in Ibbotson (2003). Tax rules from 1991 were used to construct an IRA phase-out calculator to determine $\zeta$ and $\zeta_{y}$, and household income, tax, and demographic data and NBER's TAXSIM calculator (Feenberg and Coutts, 1993) were used to construct marginal tax rates and taxes paid for each household. The estimated kernel-regression function was numerically integrated to obtain the dollar amount of implicit subsidy for every level of potential 401(k) contribution, which, with full income, was used to construct virtual full income along all portions of the budget sets.

For the private and public pension components in $\omega$ in (18), individuals were divided into cells based on exogenous demographic characteristics and the Social Security covered earnings from 1951-1991 and W-2 earnings records from 1980-1991 were used to calculate earnings histories for a synthetic-cell individual. These synthetic earnings histories were input as follows: 1) into the University of Michigan's Pension Estimation Program to calculate defined benefit pension wealth, $W^{D B}$, accrual, $\alpha^{D B}$, and change in accrual for additional earnings, $\alpha_{y^{l}}^{D B}$, for individuals with DB plans; 2) into the HRS DC/401(k) Calculator (Engelhardt, 2004) developed to calculate for individuals with defined contribution plans their DC pension wealth, $W^{D C}$, nonmatching contributions and the effect of additional earnings thereon, $F$ and $F_{y}$, respectively; the impact of additional earnings on employer match on voluntary contributions, $M_{y^{l}}^{V O L}$; required $401(\mathrm{k})$ contributions and the impact of additional earnings thereon, $Q^{M A N}$ and $Q_{y^{l}}^{M A N}$, respectively; and, 3) into the Social Security benefit calculator developed by Coile and Gruber (2000) to calculate Social Security wealth, $W^{S S}$, accrual, $\alpha^{S S}$, and change in accrual for additional earnings, $\alpha_{y^{\prime}}^{S S}$. The effect of additional earnings on the employer match to voluntary contributions, $M_{y^{l}}^{V O L}$, was calculated assuming a 401(k) contribution of 50 dollars for all individuals (regardless of actual contribution level).

Finally, the sample is likely non-random because it is based on individuals for whom the HRS was able to obtain 1) an employer-provided SPD for the 401(k) plan, and 2) permission from the individual to match SSA covered earnings and IRS W-2 earnings histories. To understand the exclusion restrictions that were developed, it is useful to note the manner in which the HRS obtained the SPDs and administrative earnings data. The HRS asked all respondents who reported being in a (current or past) pension-covered job to provide the name and address of the employer. To maintain respondent confidentiality, the HRS attempted to contact the employer, not about the respondent's pension(s), but more generally as part of a survey of pension providers in which the HRS requested copies of SPDs for the universe of pensions the employer provided (to all employees). The HRS then "matched" from this universe the appropriate pension(s) to 
the respondent based on the respondent's characteristics, e.g., union status, method of pay (hourly, salaried, commission, piece rate), occupation, tenure, etc. The "match" rates were well below 100 percent: 65 percent of those currently working in pension-covered jobs, 66 percent for the last job for those not working, and 35 percent for jobs held five years or longer prior to the current (last) job for those working (not working).

There are a number of important reasons for the failure to match an SPD to the respondent. First, the respondent may not have given correct employer name and address. Second, the HRS may have failed to receive the SPD because the employer may have refused to comply with the pension provider survey, the employer could not be located at the address given, or the employer went out of business or merged with another company and no longer existed under the name given by the respondent. Third, the employer may have submitted an SPD, but the HRS was unable to match the SPD to the respondent based on the plan detail and the respondent's characteristics. This is less likely for union and public sector workers, who are easy to identify and whose plans are easy to obtain, and more likely for workers whose employers had undergone mergers and acquisitions with subsequent plan modifications.

The exclusion restrictions were constructed as follows. First, Form 5500 data for 1988-1992 from the Department of Labor, Employee Benefit Security Administration, on the universe of pension plans with 100 or more participants and a 5 percent random sample of plans with less than 100 participants were obtained. Second, plans were divided into cells defined by Census region, employment size category, one-digit SIC code, year, and union status (union plan vs. non-union plan). The first exclusion is the incidence of pension plan outsourcing by cell in 1992, where outsourcing means the plan was administered by an entity other than the employer (weighted using sampling weights provided by DOL). The intuition here is that the HRS was less likely to have obtained an SPD from the employer if (on average in its cell) plan administration was outsourced, because more than one contact was needed (first the employer, then the plan administrator) to have received the SPD. (It may well have been that plans that were outsourced were better administered and, therefore, employers that outsourced were more likely to have returned the pension provider survey. However, this was likely more than offset because the SPD request was significantly less likely to have been fulfilled when multiple entities needed to be contacted.) The second exclusion was the incidence of pension plan consolidation due mergers and acquisitions by cell from 1988-1992. The intuition here is that the HRS was less likely either to have obtained an SPD from the employer or to have matched it to the employee if (on average in its cell) there had been a lot of plan consolidation, because plan names and detail were often changed upon consolidation. Two other variables were used as exclusions for pensions on past jobs in our selection equations: dummies for whether the individual left the job because the business closed or was laid off, respectively. These helped to measure whether the employer possibly was in financial difficulty at severance, which, if that resulted in a business failure, would have made it more difficult for the HRS to have obtained an SPD.

There were three important considerations in constructing the instruments. First, the instruments were drawn from the information set $\Omega_{t}$. Because $t$ is 1991, all 
information from 1989 and 1990 is in the information set and orthogonal to decisions made in 1991 under rational expectations. Second, because the observed marginal match and tax rates depend upon 401(k) and IRA contributions, $p^{m z} \cdot p^{I R A z}$ and $p^{401 k z}$ are based on first-dollar measures: the employer match on the first dollar contributed and the marginal tax rate at which the first dollar contributed is deductible (which equals the tax rate on the last dollar of earnings). Third, to minimize dependence on individual-specific income and family size that might be correlated with saving behavior, the first-dollar rates were calculated for a synthetic individual of each marital status assumed to have no capital income, no children, under age 65, and taking the standard deduction-where marital status is assumed exogenous - with synthetic annual labor earnings constructed as follows: individuals were divided into cells based on exogenous demographic characteristics, and the cell mean gross hourly wage rate, $\bar{w}_{t_{t-2}}$, was multiplied by 2,000 annual hours, $\bar{H}$. Let the subscript $\bullet$ denote a synthetic measure and the superscript 0 denote a first-dollar measure, then

$$
p_{\bullet j}^{m z} \cdot p_{\bullet t-2}^{I R A z} \equiv\left(1+M_{Q^{401 k} \cdot j}^{V 0}\right) \cdot\left(1-T_{I \bullet t-2}^{0} \zeta_{\bullet t-2}^{0}\right)
$$

and

$$
p_{\bullet t-2}^{401 k z} \equiv 1-T_{I \bullet t-2}^{0}\left(1-\zeta_{y_{\bullet} l_{\bullet-2}}^{0} \bar{Q}^{I R A}\right),
$$

where $\bar{Q}^{I R A}$ was set to one dollar for all individuals.

It is important to note that the tax function for $\Delta p$ in the endogenous variable $\Delta p / y^{v} \ln (\omega)$, is based on the tax system in 1991, but the tax function for the instruments is different because it is based on the tax system in 1989 (indicated by the subscript $t-2$ in (B.2)-(B.3) above). Figure 2 plots the federal marginal tax rate by real AGI (in 1991 dollars) for a single individual under 65 in 1989 and 1991. For individuals with AGI below $\$ 50,000$, the functions are essentially the same, but differ for those above this level. Specifically, above this income level in 1989, the marginal tax rate increased from 28 to 33 percent due to the phase-out of the personal exemption. However, the Budget Act of 1990 raised the top marginal tax rate to 31 percent and changed the phase-out of the personal exemption. Therefore, the non-linearity in the instruments' tax function differs from that for the endogenous regressor due to the tax-law change, which is taken as exogenous to the individual. About 15 percent of the sample is affected by this differential non-linearity in the instruments. 
Figure 1. Distribution of $401(\mathrm{k})$ Contributions for Match-Eligible Individuals

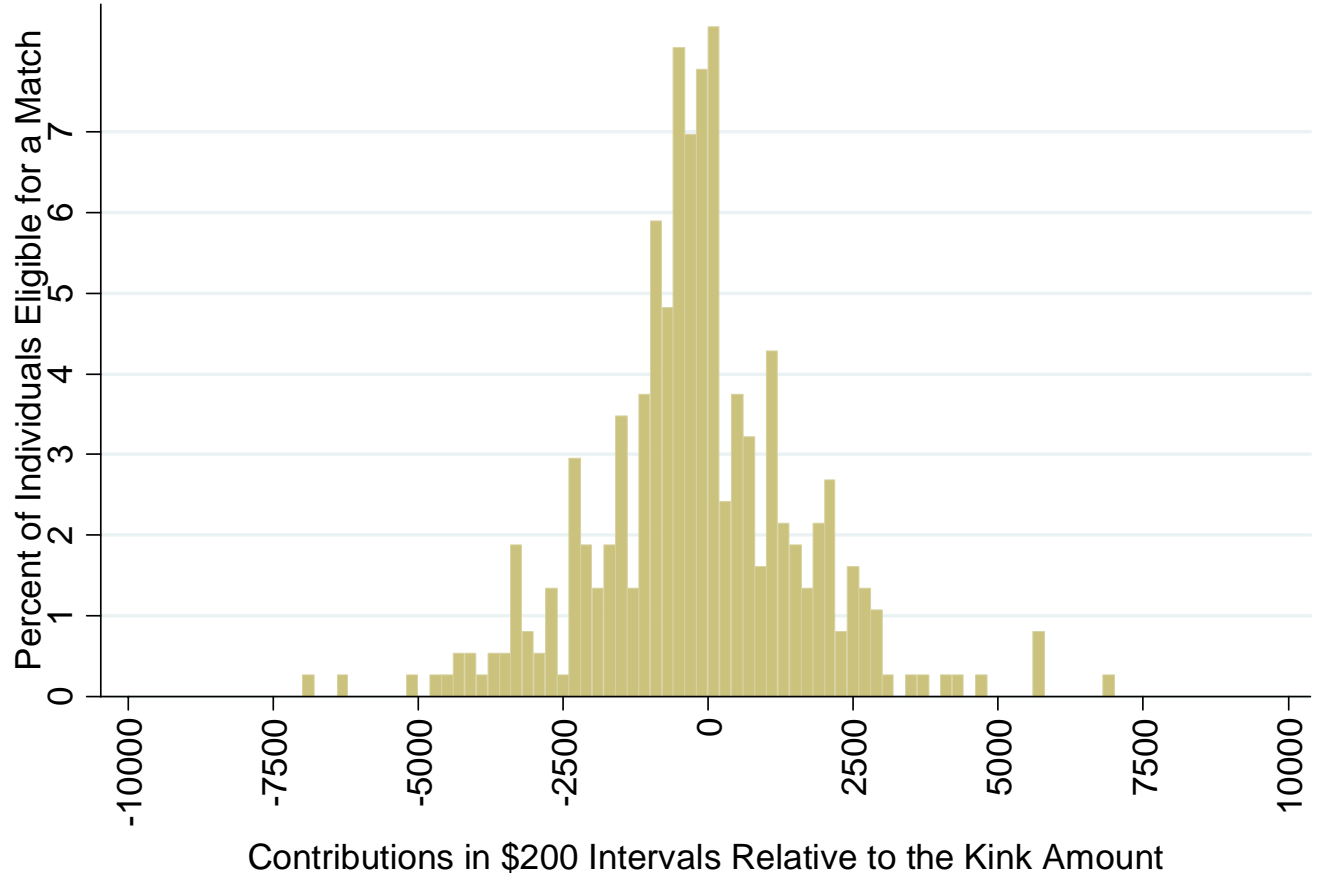


Table 1. Cap on Matching Contributions, as a Percentage of Pay, for Plans that Offer Employer Matching in the Analysis Sample

\begin{tabular}{ccccc}
\hline $\begin{array}{c}\text { Cap on Employer Matching } \\
\text { Contributions }\end{array}$ & $\begin{array}{c}(1) \\
\text { Number of } \\
\text { as a Percentage of Pay }\end{array}$ & $\begin{array}{c}\text { Percent of } \\
\text { Plans }\end{array}$ & $\begin{array}{c}\text { Number of } \\
\text { Individuals }\end{array}$ & $\begin{array}{c}\text { Percent of } \\
\text { Individuals }\end{array}$ \\
\hline Less than $2 \%$ & 7 & 3.3 & 10 & 2.7 \\
2 & 11 & 5.3 & 12 & 3.2 \\
2.5 & 1 & 0.5 & 1 & 0.3 \\
3 & 19 & 9.1 & 24 & 6.5 \\
3.75 & 1 & 0.5 & 4 & 1.0 \\
4 & 23 & 11.0 & 40 & 10.8 \\
5 & 17 & 8.1 & 53 & 14.2 \\
5.5 & 1 & 0.5 & 1 & 0.3 \\
5.7 & 1 & 0.5 & 1 & 0.3 \\
6 & 56 & 26.8 & 109 & 29.3 \\
Greater than $6 \%$ & 32 & 15.3 & 57 & 15.3 \\
No Cap & 41 & 19.6 & 60 & 16.1 \\
Total & 209 & 100.0 & 372 & 100.0 \\
\hline
\end{tabular}

Note: Authors' calculations from the HRS restricted-access pension plan data for the 209 plans associated with the 372 of the 1,042 HRS individuals in the analysis sample in plans with matching provisions. 
Table 2. Distribution of First-Dollar Match Rates as a Percentage of Contributions (1)

(4)

(5)

\begin{tabular}{ccccc} 
First-Dollar Match Rate (\%) & $\begin{array}{c}\text { Number of } \\
\text { Plans }\end{array}$ & $\begin{array}{c}\text { Percent of } \\
\text { Plans }\end{array}$ & $\begin{array}{c}\text { Number of } \\
\text { Individuals }\end{array}$ & $\begin{array}{c}\text { Percent of } \\
\text { Individuals }\end{array}$ \\
\hline 0 to 24 & 9 & 4.3 & 11 & 3.0 \\
25 & 23 & 15.3 & 43 & 11.6 \\
26 to 49 & 5 & 2.4 & 9 & 143 \\
50 & 90 & 43.1 & 34 & 38.4 \\
51 to 99 & 22 & 27.1 & 4 & 12.4 \\
100 & 57 & 1.4 & & 31.2 \\
200 & 3 & 100.0 & 372 & 1.1 \\
Total & 209 & & & 100.0 \\
\hline
\end{tabular}

Note: Authors' calculations from the HRS restricted-access pension plan data for the 209 plans associated with the 372 of the 1,042 HRS individuals in the analysis sample in plans with matching provisions. 
Table 3. Sample Means of Selected Variables in the Empirical Analysis Sample, Standard Deviations in Parentheses, Medians in Square Brackets

(1)

(2)

(3)

(4)

(5)

\begin{tabular}{|c|c|c|c|c|c|}
\hline Variable & Full Sample & $\begin{array}{c}\text { Subsample } \\
\text { without } \\
\text { Matches }\end{array}$ & $\begin{array}{l}\text { Subsample } \\
\text { with Matches }\end{array}$ & $\begin{array}{l}\text { Subsample with } \\
\text { Positive } \\
\text { Contributions }\end{array}$ & $\begin{array}{c}\text { Subsample } \\
\text { with Zero } \\
\text { Contributions }\end{array}$ \\
\hline $\begin{array}{l}\text { 401(k) Contributions (in } \\
1991 \text { dollars) }\end{array}$ & $\begin{array}{c}1377 \\
(1920) \\
{[500]}\end{array}$ & $\begin{array}{c}1232 \\
(1895) \\
{[100]}\end{array}$ & $\begin{array}{c}1640 \\
(1938) \\
{[900]}\end{array}$ & $\begin{array}{c}2446 \\
(1982) \\
{[1892]}\end{array}$ & $\begin{array}{l}0 \\
(0) \\
{[0]}\end{array}$ \\
\hline Match Rate (in percent) & $\begin{array}{c}23 \\
(37) \\
{[0]}\end{array}$ & $\begin{array}{l}0 \\
(0) \\
{[0]}\end{array}$ & $\begin{array}{l}65 \\
(32) \\
{[50]}\end{array}$ & $\begin{array}{c}28 \\
(38) \\
{[0]}\end{array}$ & $\begin{array}{c}17 \\
(33) \\
{[0]}\end{array}$ \\
\hline $\begin{array}{l}\text { After-Tax Wage } \\
\text { (in 1991 dollars per hour) }\end{array}$ & $\begin{array}{l}10.04 \\
(5.55) \\
{[8.92]}\end{array}$ & $\begin{array}{l}10.09 \\
(5.56) \\
{[9.12]}\end{array}$ & $\begin{array}{l}9.96 \\
(5.54) \\
{[8.51]}\end{array}$ & $\begin{array}{l}10.91 \\
(5.96) \\
{[9.66]}\end{array}$ & $\begin{array}{l}8.91 \\
(4.75) \\
{[8.23]}\end{array}$ \\
\hline Age (years) & $\begin{array}{l}54.9 \\
(5.2) \\
{[55.0]}\end{array}$ & $\begin{array}{l}54.9 \\
(5.1) \\
{[55.0]}\end{array}$ & $\begin{array}{c}54.8 \\
(5.4) \\
{[55.0]}\end{array}$ & $\begin{array}{c}54.7 \\
(5.0) \\
{[55.0]}\end{array}$ & $\begin{array}{l}55.1 \\
(5.5) \\
{[55.0]}\end{array}$ \\
\hline Education (years) & $\begin{array}{l}13.3 \\
(2.7) \\
{[13.0]}\end{array}$ & $\begin{array}{l}13.5 \\
(2.7) \\
{[13.0]}\end{array}$ & $\begin{array}{l}13.0 \\
(2.6) \\
{[12.0]}\end{array}$ & $\begin{array}{l}13.8 \\
(2.5) \\
{[14.0]}\end{array}$ & $\begin{array}{l}12.7 \\
(2.7) \\
{[12.0]}\end{array}$ \\
\hline Percent Female & 47 & 47 & 47 & 48 & 45 \\
\hline Percent White & 82 & 81 & 85 & 86 & 78 \\
\hline Number of Dependents & $\begin{array}{c}0.70 \\
(0.93) \\
{[0.0]}\end{array}$ & $\begin{array}{c}0.68 \\
(0.93) \\
{[0.0]}\end{array}$ & $\begin{array}{c}0.75 \\
(0.94) \\
{[0.0]}\end{array}$ & $\begin{array}{c}0.71 \\
(0.95) \\
{[0.0]}\end{array}$ & $\begin{array}{c}0.70 \\
(0.91) \\
{[0.0]}\end{array}$ \\
\hline Percent Married & 80 & 79 & 82 & 81 & 79 \\
\hline $\begin{array}{l}\text { Spouse's Education } \\
\text { (Years) }\end{array}$ & $\begin{array}{l}10.6 \\
(5.5) \\
{[12.0]}\end{array}$ & $\begin{array}{l}10.6 \\
(5.7) \\
{[12.0]}\end{array}$ & $\begin{array}{l}10.6 \\
(5.2) \\
{[12.0]}\end{array}$ & $\begin{array}{l}11.0 \\
(5.5) \\
{[12.0]}\end{array}$ & $\begin{array}{l}10.1 \\
(5.5) \\
{[12.0]}\end{array}$ \\
\hline $\begin{array}{l}\text { Percent with Plans that } \\
\text { Allow Borrowing }\end{array}$ & 36 & 19 & 68 & 42 & 29 \\
\hline $\begin{array}{l}\text { Percent with Plans that } \\
\text { Allow Hardship } \\
\text { Withdrawals }\end{array}$ & 4 & 4 & 5 & 6 & 2 \\
\hline
\end{tabular}




\begin{tabular}{|c|c|c|c|c|c|}
\hline Variable & Full Sample & $\begin{array}{l}\text { Subsample } \\
\text { without } \\
\text { Matches }\end{array}$ & $\begin{array}{c}\text { Subsample } \\
\text { with Matches }\end{array}$ & $\begin{array}{c}\text { Subsample } \\
\text { with Positive } \\
\text { Contributions }\end{array}$ & $\begin{array}{c}\text { Subsample } \\
\text { with Zero } \\
\text { Contributions }\end{array}$ \\
\hline $\begin{array}{l}\text { Percent with Plans that } \\
\text { Allow Self-Directed } \\
\text { Investment }\end{array}$ & 63 & 46 & 92 & 66 & 58 \\
\hline $\begin{array}{l}\text { Percent with Other } \\
\text { Pensions at the Firm }\end{array}$ & 47 & 53 & 34 & 45 & 48 \\
\hline $\begin{array}{l}\text { Percent with Plan Limit } \\
\text { less than Federal Limit }\end{array}$ & 80 & 73 & 92 & 76 & 85 \\
\hline $\begin{array}{l}\text { Percent with Plan that } \\
\text { Allows After-Tax Saving }\end{array}$ & 23 & 9 & 47 & 26 & 18 \\
\hline $\begin{array}{l}\text { Percent that had } \\
\text { Employer-Sponsored } \\
\text { Retirement Seminar }\end{array}$ & 23 & 23 & 23 & 25 & 20 \\
\hline $\begin{array}{l}\text { Percent with a Spouse } \\
\text { who has a Pension }\end{array}$ & 39 & 39 & 38 & 42 & 35 \\
\hline Percent in a Union & 34 & 39 & 27 & 28 & 43 \\
\hline Number of Observations & 1042 & 670 & 372 & 588 & 454 \\
\hline
\end{tabular}


Table 4. Mean Potential and Unused Employer Matching Contributions for the Sub-sample of Individuals Eligible for Employer Matching Contributions, Standard Deviations in Parentheses, Medians in Square Brackets

\section{(1)}

\begin{tabular}{|c|c|c|c|}
\hline Variable & Overall & $\begin{array}{l}\text { Sub-sample with } \\
\text { Positive } \\
\text { Contributions }\end{array}$ & $\begin{array}{c}\text { Sub-sample } \\
\text { with Zero } \\
\text { Contributions }\end{array}$ \\
\hline Potential Employer & 1249 & 1362 & 1021 \\
\hline Matching Contributions in & (1409) & $(1153)$ & $(1804)$ \\
\hline 1991 dollars & [939] & [1068] & [714] \\
\hline Potential Employer & 3.8 & 3.9 & 3.8 \\
\hline Matching Contributions & (4.1) & $(2.8)$ & $(5.8)$ \\
\hline as a Percentage of Pay & {$[3.0]$} & {$[3.5]$} & {$[3.0]$} \\
\hline Unused Employer & 550 & 319 & 1013 \\
\hline Matching Contributions in & (1243) & $(741)$ & (1798) \\
\hline 1991 dollars & {$[205]$} & {$[0]$} & [710] \\
\hline Unused Employer & 1.9 & 1.0 & 3.7 \\
\hline Matching Contributions & $(4.0)$ & $(2.0)$ & (5.9) \\
\hline as a Percentage of Pay & {$[1.0]$} & {$[0]$} & {$[3.0]$} \\
\hline
\end{tabular}


Table 5. Selected Parameter Estimates of the Effect of Liquidity Constraints on the Extent that Contributions are Less than the Cap, Standard Errors in Parentheses

\begin{tabular}{|c|c|c|c|c|}
\hline & (1) & (2) & (3) & (4) \\
\hline & & & mator and Depende & Variable \\
\hline & & Probit & Tobit & Tobit \\
\hline Explanatory Variables & $\begin{array}{l}\text { Sample } \\
\text { Mean }\end{array}$ & $\begin{array}{c}\text { Dummy if } \\
\text { Contribution } \\
\text { Below the Cap }\end{array}$ & $\begin{array}{l}\text { Dollar Amount } \\
\text { that Contribution } \\
\text { is Below the Cap }\end{array}$ & $\begin{array}{l}\text { Amount Contribution is } \\
\text { Below the Cap as a } \\
\text { Percent of Pay }\end{array}$ \\
\hline Dummy if Has a Home & 0.19 & -0.524 & -649.4 & -0.014 \\
\hline Equity Line of Credit & & $(0.198)$ & (171.3) & $(0.004)$ \\
\hline Dummy if Financial & 0.11 & 0.725 & 81.1 & 0.004 \\
\hline Distress Due to & & $(0.291)$ & (202.4) & $(0.004)$ \\
\hline Unexpected Medical & & & & \\
\hline Expenses & & & & \\
\hline Dummy if Financial & 0.06 & -0.569 & -733.8 & -0.017 \\
\hline Distress Due to & & $(0.366)$ & $(360.8)$ & $(0.014)$ \\
\hline Unemployment & & & & \\
\hline Dummy if No Capital & 0.23 & 0.552 & 220.1 & 0.009 \\
\hline Income & & $(0.180)$ & $(136.0)$ & $(0.003)$ \\
\hline Education (years) & 12.97 & -0.077 & -41.4 & -0.002 \\
\hline & & $(0.036)$ & $(26.5)$ & $(0.001)$ \\
\hline
\end{tabular}

Note: This table shows selected parameter estimates from ad hoc reduced-form selection-corrected specifications of the impact of selected variables that proxy for the ability to borrow on whether and to what extent employer matching contributions go unused on the sub-sample of 372 individuals in $401(\mathrm{k})$ plans that offer employer matching. Standard errors are in parentheses. The fraction of individuals with contributions below the cap is 0.54 . The average dollar amount that the contribution is below the cap is $\$ 953$, which, for average pay of $\$ 33,377$, represented 3 percent of pay. The specifications also control for age, dummy variables if married, white, home owner, and can rely on private income transfers under financial distress, as well as a constant. The selection equations for the specifications used the same exclusion restrictions as in Table 7 and explained in the text. 
Table 6. Selected Parameter Estimates from Ad Hoc Reduced-Form Specifications Similar to Previous Literature, Standard Errors in Parentheses

\begin{tabular}{|c|c|c|c|c|}
\hline \multicolumn{5}{|c|}{$\begin{array}{l}\text { (2) } \\
\text { Estimator and Dependent Variable }\end{array}$} \\
\hline & Probit & OLS & OLS & $\begin{array}{l}\text { One-Limit } \\
\text { Tobit }\end{array}$ \\
\hline $\begin{array}{l}\text { Explanatory } \\
\text { Variables }\end{array}$ & $\begin{array}{l}\text { Dummy if } \\
\text { Contributed }\end{array}$ & Contribution & Contribution & Contribution \\
\hline $\begin{array}{l}\text { Dummy if Plan } \\
\text { Offers a Match }\end{array}$ & $\begin{array}{c}0.284 \\
(0.175)\end{array}$ & $\begin{array}{c}595.4 \\
(209.7)\end{array}$ & $\begin{array}{c}549.4 \\
(206.9)\end{array}$ & $\begin{array}{c}865.7 \\
(331.7)\end{array}$ \\
\hline $\begin{array}{l}\text { First-Dollar } \\
\text { Match Rate }\end{array}$ & $\begin{array}{c}0.220 \\
(0.228)\end{array}$ & $\begin{array}{l}-255.2 \\
(271.2)\end{array}$ & $\begin{array}{l}-170.3 \\
(266.3)\end{array}$ & $\begin{array}{l}-42.6 \\
(427.2)\end{array}$ \\
\hline $\begin{array}{l}\text { Dummy if } \\
\text { Female }\end{array}$ & $\begin{array}{c}0.316 \\
(0.112)\end{array}$ & $\begin{array}{l}389.1 \\
(121.2)\end{array}$ & $\begin{array}{c}304.7 \\
(135.6)\end{array}$ & $\begin{array}{l}639.3 \\
(224.9)\end{array}$ \\
\hline $\begin{array}{l}\text { Dummy if } \\
\text { White }\end{array}$ & $\begin{array}{c}0.262 \\
(0.107)\end{array}$ & $\begin{array}{c}302.1 \\
(133.2)\end{array}$ & $\begin{array}{c}275.6 \\
(131.2)\end{array}$ & $\begin{array}{l}617.1 \\
(223.2)\end{array}$ \\
\hline $\begin{array}{l}\text { Education } \\
\text { (Years) }\end{array}$ & $\begin{array}{c}0.043 \\
(0.018)\end{array}$ & $\begin{array}{l}105.8 \\
(22.4)\end{array}$ & $\begin{array}{c}89.4 \\
(22.5)\end{array}$ & $\begin{array}{l}147.6 \\
(38.2)\end{array}$ \\
\hline $\begin{array}{l}\text { Earnings } \\
\text { Entered as }\end{array}$ & Quartic & Linear & Quartic & Quartic \\
\hline $\begin{array}{l}\text { Match Rate } \\
\text { Elasticity }\end{array}$ & $\begin{array}{c}0.037 \\
(0.043)\end{array}$ & $\begin{array}{l}-0.042 \\
(0.045)\end{array}$ & $\begin{array}{l}-0.028 \\
(0.044)\end{array}$ & $\begin{array}{l}-0.005 \\
(0.003)\end{array}$ \\
\hline$R^{2}$ & --- & 0.31 & 0.34 & --- \\
\hline \multicolumn{5}{|c|}{$\begin{array}{l}\text { Note: This table shows selected parameter estimates for ad hoc reduced-form models } \\
\text { similar to those in the previous literature, estimated with the sample of } 1042 \\
\text { individuals described in the text. Standard errors in parentheses. In columns 1,3, and } \\
\text { 4, earnings were entered as a quartic function and in column } 2 \text { linearly. Additional } \\
\text { explanatory variables in the specifications included a quartic in age, married, number } \\
\text { of children, spouse's education, a quartic in spouse's age, and a constant. For the Probit } \\
\text { equation in column (1) and the Tobit equation in column (4) bootstrapped standard } \\
\text { errors reported for the match rate elasticity. }\end{array}$} \\
\hline
\end{tabular}


Table 7. Selected Parameter Estimates, Marginal Effects, and Elasticities of 401(k) Participation, Standard Errors in Parentheses

\begin{tabular}{|c|c|c|c|c|c|c|}
\hline & $(1)$ & $(2)$ & (3) & (4) & $(5)$ & $(6)$ \\
\hline Explanatory Variable & with Selection & $\begin{array}{c}\text { IV } \\
\text { with Selection } \\
\end{array}$ & $\begin{array}{c}\text { IV } \\
\text { without Selection }\end{array}$ & $\begin{array}{c}\text { IV } \\
\text { with Selection } \\
\end{array}$ & $\begin{array}{c}\text { IV } \\
\text { with Selection } \\
\end{array}$ & $\begin{array}{c}\text { IV } \\
\text { with Selection } \\
\end{array}$ \\
\hline \multicolumn{7}{|l|}{ A. Parameter Estimates } \\
\hline$\Delta p / y \ln (\omega)$ & $\begin{array}{l}-2.567 \\
(2.233)\end{array}$ & $\begin{array}{c}0.384 \\
(7.227)\end{array}$ & $\begin{array}{l}-0.093 \\
(6.983)\end{array}$ & $\begin{array}{l}-4.522 \\
(6.712)\end{array}$ & $\begin{array}{l}-7.209 \\
(8.004)\end{array}$ & $\begin{array}{l}-7.486 \\
(7.504)\end{array}$ \\
\hline$A g e \times \Delta p / y \ln (\omega)$ & $\begin{array}{c}0.009 \\
(0.033)\end{array}$ & $\begin{array}{l}-0.083 \\
(0.084)\end{array}$ & $\begin{array}{l}-0.073 \\
(0.081)\end{array}$ & $\begin{array}{l}-0.024 \\
(0.078)\end{array}$ & $\begin{array}{l}-0.010 \\
(0.093)\end{array}$ & $\begin{array}{c}0.044 \\
(0.092)\end{array}$ \\
\hline Female $\times \Delta p / y \ln (\omega)$ & $\begin{array}{c}0.283 \\
(0.367)\end{array}$ & $\begin{array}{l}-0.520 \\
(0.861)\end{array}$ & $\begin{array}{l}-0.565 \\
(0.848)\end{array}$ & $\begin{array}{c}0.639 \\
(0.891)\end{array}$ & $\begin{array}{c}0.857 \\
(1.076)\end{array}$ & $\begin{array}{c}0.913 \\
(1.030)\end{array}$ \\
\hline White $\times \Delta p / y \ln (\omega)$ & $\begin{array}{c}1.070 \\
(0.492)\end{array}$ & $\begin{array}{c}1.570 \\
(1.131)\end{array}$ & $\begin{array}{c}1.406 \\
(1.126)\end{array}$ & $\begin{array}{c}1.498 \\
(1.076)\end{array}$ & $\begin{array}{c}1.057 \\
(1.209)\end{array}$ & $\begin{array}{c}1.006 \\
(1.166)\end{array}$ \\
\hline Married $\times \Delta p / y \ln (\omega)$ & $\begin{array}{l}-0.409 \\
(0.460)\end{array}$ & $\begin{array}{l}-0.792 \\
(1.175)\end{array}$ & $\begin{array}{l}-0.842 \\
(1.145)\end{array}$ & $\begin{array}{c}0.279 \\
(1.089)\end{array}$ & $\begin{array}{c}0.848 \\
(1.234)\end{array}$ & $\begin{array}{c}0.745 \\
(1.192)\end{array}$ \\
\hline Education $\times \Delta p / y \ln (\omega)$ & $\begin{array}{c}0.145 \\
(0.066)\end{array}$ & $\begin{array}{c}0.600 \\
(0.181)\end{array}$ & $\begin{array}{c}0.604 \\
(0.182)\end{array}$ & $\begin{array}{c}0.519 \\
(0.165)\end{array}$ & $\begin{array}{c}0.677 \\
(0.188)\end{array}$ & $\begin{array}{c}0.438 \\
(0.190)\end{array}$ \\
\hline$\kappa$ & $\begin{array}{c}0.251 \\
(0.059)\end{array}$ & $\begin{array}{c}0.653 \\
(0.442)\end{array}$ & $\begin{array}{c}0.665 \\
(0.424)\end{array}$ & $\begin{array}{c}0.390 \\
(0.416)\end{array}$ & $\begin{array}{c}0.293 \\
(0.478)\end{array}$ & $\begin{array}{c}0.129 \\
(0.500)\end{array}$ \\
\hline Selection Term & $\begin{array}{l}-2.3140 \\
(1.3683)\end{array}$ & $\begin{array}{l}-1.4202 \\
(0.6495)\end{array}$ & & $\begin{array}{l}-2.8518 \\
(1.3841)\end{array}$ & $\begin{array}{l}-2.1514 \\
(1.2562)\end{array}$ & $\begin{array}{l}-1.7861 \\
(1.0074)\end{array}$ \\
\hline $\begin{array}{c}p \text {-Value for Test of Null } \\
\text { No Match Effect } \\
\text { No Selection }\end{array}$ & $\begin{array}{l}0.0001 \\
0.0908\end{array}$ & $\begin{array}{l}0.0001 \\
0.0288\end{array}$ & 0.0001 & $\begin{array}{l}0.0001 \\
0.0394\end{array}$ & $\begin{array}{l}0.0001 \\
0.0868\end{array}$ & $\begin{array}{l}0.0001 \\
0.0762\end{array}$ \\
\hline Selection-Equation Excl & & & & & & \\
\hline Plan Outsourcing & $\begin{array}{c}-0.0829 \\
(0.0272)\end{array}$ & $\begin{array}{c}-0.0929 \\
(0.0267)\end{array}$ & & $\begin{array}{c}-0.0929 \\
(0.0267)\end{array}$ & $\begin{array}{c}-0.1173 \\
(0.0275)\end{array}$ & $\begin{array}{c}-0.1321 \\
(0.0278)\end{array}$ \\
\hline Plan Consolidation & $\begin{array}{c}-0.1207 \\
(0.0360)\end{array}$ & $\begin{array}{c}-0.1510 \\
(0.0368)\end{array}$ & & $\begin{array}{c}-0.1510 \\
(0.0368)\end{array}$ & $\begin{array}{c}-0.1910 \\
(0.0402)\end{array}$ & $\begin{array}{c}-0.1868 \\
(0.0400)\end{array}$ \\
\hline Business Closure & $\begin{array}{l}-0.0683 \\
(0.0172)\end{array}$ & $\begin{array}{l}-0.0530 \\
(0.0173)\end{array}$ & & $\begin{array}{l}-0.0530 \\
(0.0173)\end{array}$ & $\begin{array}{l}-0.0530 \\
(0.0170)\end{array}$ & $\begin{array}{l}-0.0481 \\
(0.0172)\end{array}$ \\
\hline Laid Off & $\begin{array}{c}-0.0225 \\
(0.0238)\end{array}$ & $\begin{array}{c}-0.0110 \\
(0.0239)\end{array}$ & & $\begin{array}{l}-0.0110 \\
(0.0239)\end{array}$ & $\begin{array}{l}-0.0067 \\
(0.0240)\end{array}$ & $\begin{array}{c}0.0018 \\
(0.0239)\end{array}$ \\
\hline
\end{tabular}


(1)

(2)

B. Additional Controls

Fringe Benefit, and Plan

Characteristics?

Interaction of firm size with Fringe

Benefits and Plan characteristics

Occupation and Interactions of

Occupation with Demographics,

Fringe Benefits, Plan

Characteristics, and Other

Employment Characteristics?

C. Marginal Effect on Probability of Participation with Respect to

Match Rate

(additional \$1 per \$1 contributed)

0.0091

[0.00001,0.0907]

0.2695

0.4724

0.0944

0.1833

0.1997

Virtual Full Income

(additional \$100,000)

Net Wage

(additional \$1 per hour)

Marginal Tax Rate

(increase of 10 percentage points)

Predicted Probability of

Participation

[0.0243,0.5918]

$[0.2747,0.6843]$

$-0.1416$

$[-0.0271,-0.00001] \quad[-0.1773,-0.0073]$

$-0.0001$

$-0.0026$

$[-0.2050,-0.0823]$

$-0.0046$

$[-0.0008,-0.00001] \quad[-0.0057,-0.0002]$

0.0053

0.1583

$[0.00001,0.0533]$

0.97

$[0.0143,0.3477]$

0.86

0.0721

0.0021

$[0.0000,0.0216]$

$-0.0032$

$[0.0073,0.1641]$

$-0.1053$

$[-0.0316,0.0000]$

$[-0.2397,-0.0106] \quad[-0.4074,-0.1664$
$[-0.0066,-0.0026]$

0.2775

[0.1614,0.4020]

0.57

0.1907

$-0.2785$
[0.1139,0.2789]

$[-0.2397,-0.0106] \quad[-0.4074,-0.1664]$
(5)

(6)

Yes

Yes Yes

No

Yes
Full Income
[0.00007,0.4798]

$-0.0283$

$[-0.1438,-.00002]$

$-0.0009$

$[-0.0046,-0.00001]$

0.0555

[0.00004,0.2819]

0.94

0.0231

[0,0.1149]

$-0.0337$

$[-0.1679,0]$
$[0.0017, .6551763$

$-0.0549$

[-0.1963,-0.0005]

$-0.0018$

$[-0.0063,-0.00001]$

0.1077

[0.0010,0.3849]

0.88

0.0479

[0.0005,0.1743]

$-0.0700$

[-0.2546,-0.0008]
[0.0173,0.7522]

$-0.0598$

[-0.2254,-0.0052]

$-0.0019$

$[-0.0073,-0.0002]$

0.1173

[0.0102,0.4419]

0.81

0.0567

[0.0048,0.2043]

$-0.0828$

$[-0.2984,-0.0070]$ 
Net Wage

Marginal Tax Rate

$-0.0013$

$[-0.0125,0.0000]$

0.0013

$-0.0416$

$[0.0000,0.0132]$

$[-0.0946,-0.0042]$

0.0439

$-0.1101$

$[-0.1611,-0.0658]$

0.1162

[0.0044,0.1000]

$[0.0694,0.1701]$

$-0.0133$

$[-0.0663,0]$

0.0141

$[0,0.0701]$

$-0.0277$

[-0.1006,-0.0003]

0.0292

$0.0003,0.1063]$

$-0.0327$

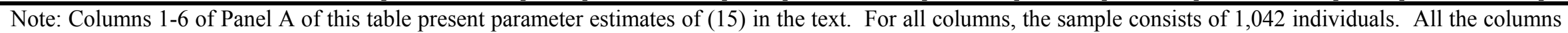

except the first assume prices, net wage, and virtual income are endogenous. Columns 2 and 4-6 present selection-corrected estimates using the exclusion restrictions

discussed in the text and the appendix. The parameter estimates for the selection term in the participation equation are shown in Panel A. Panel A also presents

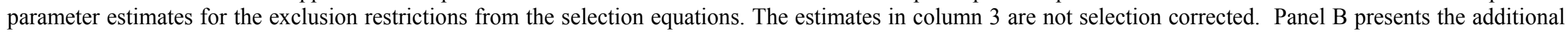
controls included. Marginal effects evaluated at the mean of the regressors are shown in panel C. Panel D presents estimates of elasticities of 401(k) participation

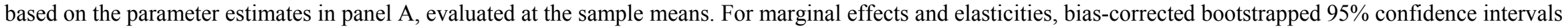
are reported in square brackets. 
Table 8. Estimated Marginal Effects and Elasticities for PIGLOG Utility by Demographic Groups

\begin{tabular}{|c|c|c|c|c|c|c|c|}
\hline & $(1)$ & $(2)$ & (3) & (4) & $(5)$ & $(6)$ & $(7)$ \\
\hline Measure & Female & Male & $\begin{array}{l}\text { High School } \\
\text { Dropout }\end{array}$ & $\begin{array}{l}\text { High School } \\
\text { Diploma }\end{array}$ & Some College & College Degree & $\begin{array}{c}\text { Graduate } \\
\text { School }\end{array}$ \\
\hline \multirow{2}{*}{$\begin{array}{l}\text { Participation Marginal Effect } \\
\text { from the Match Rate }\end{array}$} & 0.2259 & 0.1750 & 0.0670 & 0.1725 & 0.2177 & 0.2532 & 0.2633 \\
\hline & {$[0.0081,0.5900]$} & {$[0.0012,0.7843]$} & {$[-0.1326,0.7177]$} & {$[0.0071,0.6336]$} & {$[0.0075,0.5620]$} & {$[0.0146,0.8546]$} & {$[0.0147,0.8736]$} \\
\hline \multirow{2}{*}{$\begin{array}{l}\text { Participation Elasticity with } \\
\text { Respect to the Match Rate }\end{array}$} & 0.0761 & 0.0714 & 0.0289 & 0.0729 & 0.0809 & 0.1323 & 0.0483 \\
\hline & {$[0.0047,0.2030]$} & {$[0.0005,0.3192]$} & {$[-0.0530,0.3131]$} & {$[0.0028,0.2667]$} & {$[0.0028,0.2057]$} & {$[0.0078,0.4518]$} & {$[0.0028,0.1620]$} \\
\hline
\end{tabular}

Note: This table shows estimated marginal effects and elasticities of participation with respect to the employer match rate by sex and education group based on the parameter estimates from the richest specification, shown in column 6 of Table 7, evaluated at the sample means. The elasticities are based on group specific participation probability and match rate. Bias-corrected bootstrapped $95 \%$ confidence intervals are reported in square brackets. 
Table 9. Instrumental-Variable Parameter Estimates of 401(k) Contributions for Selected Variables, Standard Errors in Parentheses

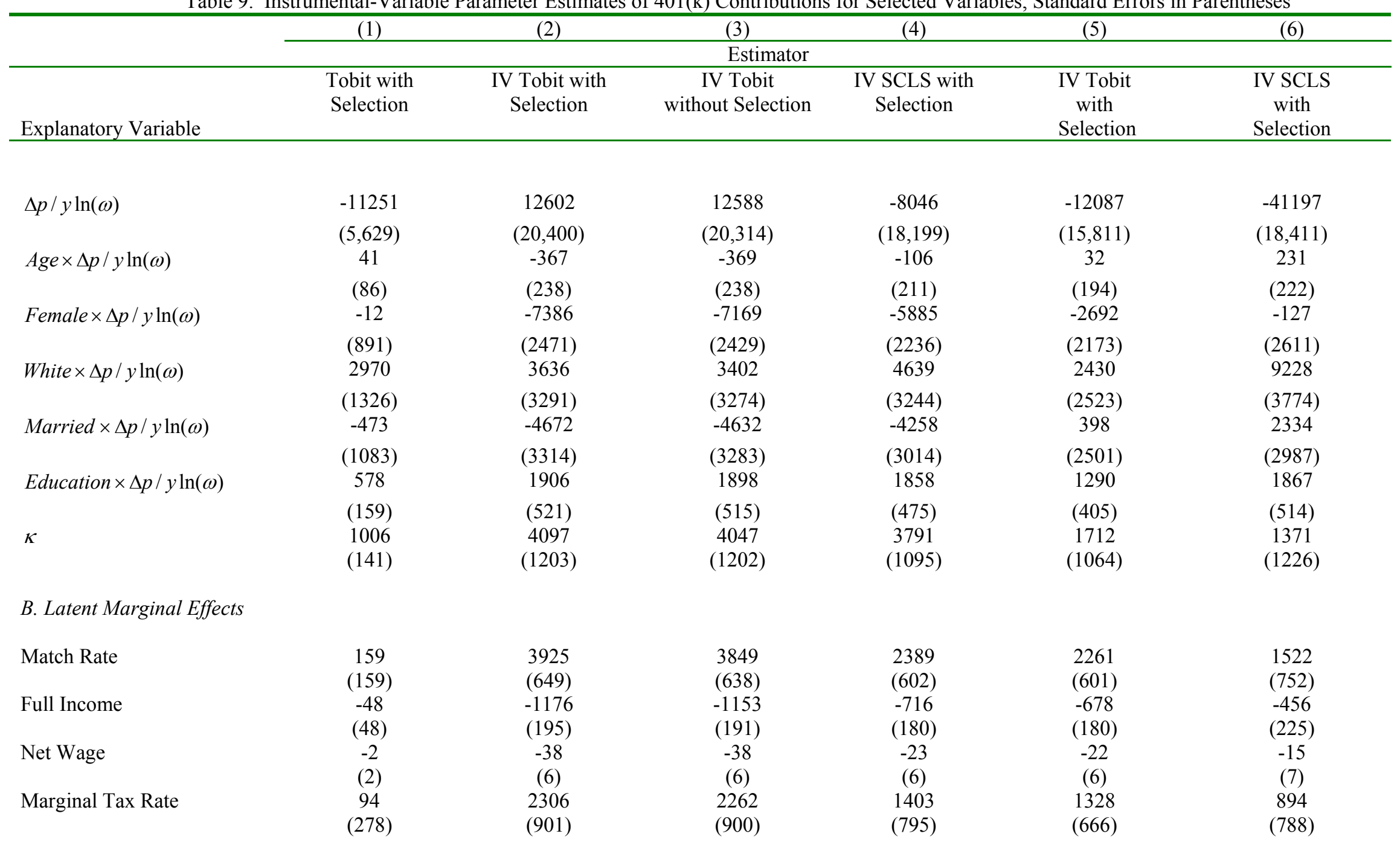


C. Parameter Estimates for Selection Term in Contribution Equation and Exclusion Restrictions in the Selection Equation

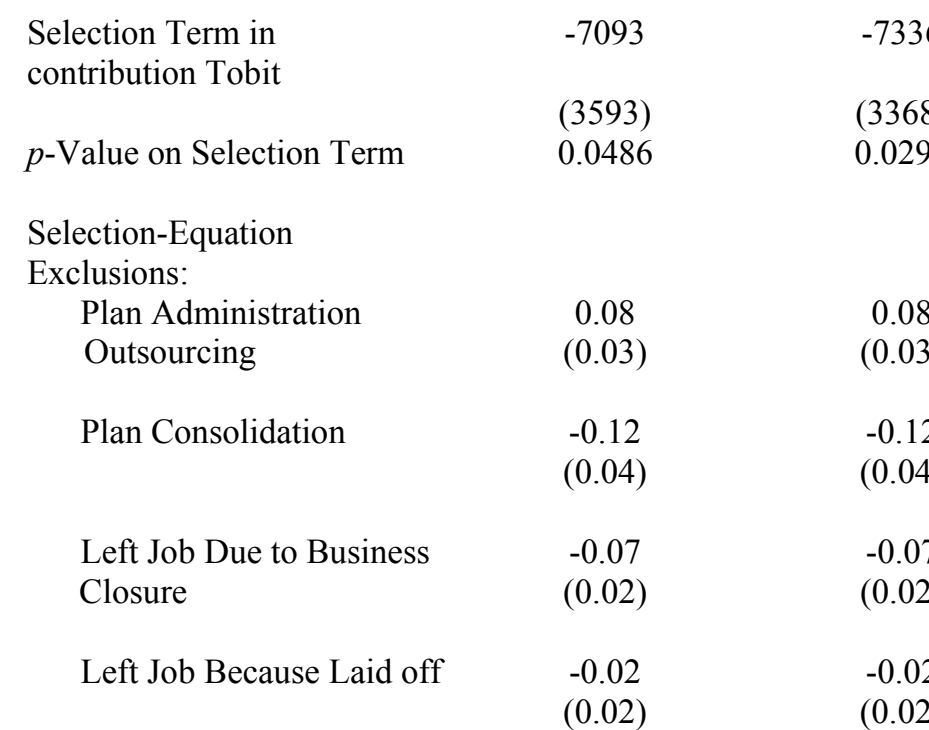

-7336
$(3368)$
.0296

$\begin{array}{lll}-6468 & -4172 & -3981 \\ (3157) & (2104) & (2611) \\ 0.0409 & 0.0476 & 0.1282\end{array}$

\section{Additional Controls}

Fringe Benefit, and Plan

Characteristics?

Interaction of firm size with

Fringe Benefits and Plan

characteristics

Occupation and Interactions

of Occupation with

Demographics, Fringe

Benefits, Plan Characteristics,

and Other Employment

Characteristics?

$\begin{array}{llcccc}\text { No } & \text { No } & \text { No } & \text { No } & \text { Yes } & \text { Yes } \\ \text { No } & \text { No } & \text { No } & \text { No } & \text { Yes } & \text { Yes } \\ \text { No } & \text { No } & \text { No } & \text { No } & \text { Yes } & \text { Yes }\end{array}$


E. Estimated Elasticity with Respect to

Match Rate

Full Income

Net Wage

Marginal Tax Rate

Match Rate

Full Income

Net Wage

Marginal Tax Rate

Match Rate

Full Income

Net Wage

Marginal Tax Rate

\begin{tabular}{|c|c|c|c|}
\hline \multicolumn{4}{|c|}{ Total } \\
\hline 0.0061 & 0.0937 & 0.1193 & 0.1202 \\
\hline$[-0.007,0.0202]$ & {$[0.0649,0.1818]$} & {$[0.0719,0.213]$} & {$[0.0736,0.2667]$} \\
\hline-0.0206 & -0.3213 & -0.4085 & -0.4115 \\
\hline$[-0.0696,0.0241]$ & {$[-0.6226,-0.2222]$} & {$[-0.729,-0.2468]$} & {$[-0.9132,-0.2519]$} \\
\hline-0.0082 & -0.1270 & -0.1615 & -0.1626 \\
\hline$[-0.0274,0.0094]$ & {$[-0.2461,-0.0876]$} & {$[-0.2882,-0.0975]$} & {$[-0.3609,-0.0996]$} \\
\hline 0.0087 & 0.1340 & 0.1704 & 0.1718 \\
\hline \multirow[t]{2}{*}[-0.0101,0.0291]{} & {$[0.0926,0.2599]$} & {$[0.1029,0.3042]$} & {$[0.105,0.381]$} \\
\hline & & Extensive Margin & \\
\hline 0.0007 & 0.0483 & 0.0745 & 0.0659 \\
\hline$[-0.0002,0.0197]$ & {$[0.0265,0.1003]$} & {$[0.0448,0.1331]$} & {$[0.0366,0.1687]$} \\
\hline-0.0023 & -0.1654 & -0.2554 & -0.2254 \\
\hline$[-0.0675,0.0014]$ & {$[-0.3433,-0.0907]$} & {$[-0.456,-0.1537]$} & {$[-0.5777,-0.1254]$} \\
\hline-0.0009 & -0.0654 & -0.1010 & -0.0891 \\
\hline$[-0.0265,0.0005]$ & {$[-0.1357,-0.0359]$} & {$[-0.1802,-0.0607]$} & {$[-0.2282,-0.0494]$} \\
\hline 0.0009 & 0.0691 & 0.1066 & 0.0940 \\
\hline \multirow[t]{2}{*}[-0.0005,0.0281]{} & {$[0.0377,0.1432]$} & {$[0.0642,0.1903]$} & {$[0.0523,0.2411]$} \\
\hline & & Intensive Margin & \\
\hline 0.0054 & 0.0455 & 0.0448 & 0.0544 \\
\hline$[-0.0049,0.0157]$ & {$[0.026,0.0816]$} & {$[0.0267,0.0797]$} & {$[0.0337,0.098]$} \\
\hline-0.0183 & -0.1556 & -0.1530 & -0.1863 \\
\hline$[-0.0539,0.0169]$ & {$[-0.2791,-0.0898]$} & {$[-0.273,-0.0919]$} & {$[-0.3353,-0.1158]$} \\
\hline-0.0073 & -0.0616 & -0.0605 & -0.1327 \\
\hline$[-0.0213,0.0066]$ & {$[-0.1104,-0.0354]$} & {$[-0.1078,-0.0363]$} & {$[-0.0457,0.0195]$} \\
\hline 0.0077 & 0.0649 & 0.0637 & 0.0778 \\
\hline$[-0.007,0.0225]$ & {$[0.0373,0.1165]$} & {$[0.0382,0.1139]$} & {$[0.0483,0.1399]$} \\
\hline
\end{tabular}

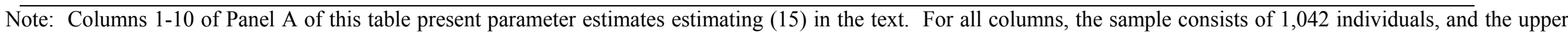

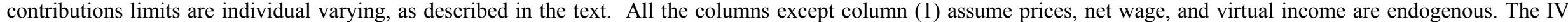

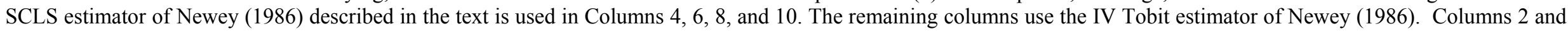


4-10 present selection-corrected estimates using the exclusion restrictions discussed in the text and the appendix. Marginal effects evaluated at the mean of the regressors are shown in panel B. The units of measure for the marginal effects are the same as those in Table 7: for the match rate, an additional $\$ 1$ per $\$ 1$ contributed; for virtual full income, an additional $\$ 100,000$; for the net wage, an additional $\$ 1$ per hour; and for the marginal tax rate, an increase of 10 percentage points. The parameter estimates for the selection term in the structural contribution equation are shown in Panel C. Panel C also presents parameter estimates for the exclusion restrictions from the selection equations. The estimates in column 3 are not selection corrected. Panel D presented the additional controls included. Panel E presents estimates of elasticities of 401(k) contributions based on the structural parameter estimates in panel A, evaluated at the sample means. The elasticities on the extensive and intensive margins were calculated using the McDonald and Moffitt (1980) decomposition, respectively. For elasticities, bias-corrected bootstrapped 95\% confidence intervals are reported in square brackets. 
Table 10. Estimated Marginal Effects and Elasticities by Demographic Groups

\begin{tabular}{|c|c|c|c|c|c|c|c|}
\hline & $(1)$ & $(2)$ & (3) & $(4)$ & $(5)$ & $(6)$ & $(7)$ \\
\hline Measure & Female & Male & $\begin{array}{l}\text { High School } \\
\text { Dropout }\end{array}$ & $\begin{array}{l}\text { High School } \\
\text { Diploma }\end{array}$ & Some College & College Degree & $\begin{array}{l}\text { Graduate } \\
\text { School }\end{array}$ \\
\hline $\begin{array}{l}\text { Marginal Effect } \\
\text { from the Match Rate }\end{array}$ & $\begin{array}{c}1153 \\
{[742,3013]}\end{array}$ & $\begin{array}{c}1752 \\
{[902,3480]}\end{array}$ & $\begin{array}{c}396 \\
{[-232,2484]}\end{array}$ & $\begin{array}{c}1178 \\
{[611,3042]}\end{array}$ & $\begin{array}{c}1700 \\
{[1080,3415]}\end{array}$ & $\begin{array}{c}2366 \\
{[1545,3963]}\end{array}$ & $\begin{array}{c}2693 \\
{[1788,4434]}\end{array}$ \\
\hline Total Match Elasticity & $\begin{array}{c}0.1202 \\
{[0.0773,0.3141]}\end{array}$ & $\begin{array}{c}0.1934 \\
{[0.0995,0.3842]}\end{array}$ & $\begin{array}{c}0.0540 \\
{[-0.0317,0.3383]}\end{array}$ & $\begin{array}{c}0.1478 \\
{[0.0766,0.3819]}\end{array}$ & $\begin{array}{c}0.1804 \\
{[0.1146,0.3624]}\end{array}$ & $\begin{array}{c}0.3352 \\
{[0.2189,0.5614]}\end{array}$ & $\begin{array}{c}0.1306 \\
{[0.0867,0.215]}\end{array}$ \\
\hline $\begin{array}{l}\text { Extensive Margin } \\
\text { (Participation) Elasticity }\end{array}$ & $\begin{array}{c}0.0671 \\
{[0.0361,0.1996]}\end{array}$ & $\begin{array}{c}0.1035 \\
{[0.0524,0.2491]}\end{array}$ & $\begin{array}{c}0.0320 \\
{[-0.0197,0.2172]}\end{array}$ & $\begin{array}{c}0.0825 \\
{[0.0349,0.2426]}\end{array}$ & $\begin{array}{c}0.0971 \\
{[0.0557,0.2296]}\end{array}$ & $\begin{array}{c}0.1726 \\
{[0.0875,0.3709]}\end{array}$ & $\begin{array}{c}0.0656 \\
{[0.0341,0.1384]}\end{array}$ \\
\hline $\begin{array}{l}\text { Intensive Margin } \\
\text { Elasticity }\end{array}$ & $\begin{array}{c}0.0532 \\
{[0.0344,0.1146]}\end{array}$ & $\begin{array}{c}0.0900 \\
{[0.055,0.1697]}\end{array}$ & $\begin{array}{c}0.0223 \\
{[-0.0071,0.1212]}\end{array}$ & $\begin{array}{c}0.0654 \\
{[0.037,0.1393]}\end{array}$ & $\begin{array}{c}0.0833 \\
{[0.0576,0.1453]}\end{array}$ & $\begin{array}{c}0.1630 \\
{[0.1195,0.2706]}\end{array}$ & $\begin{array}{c}0.0648 \\
{[0.0493,0.1059]}\end{array}$ \\
\hline
\end{tabular}

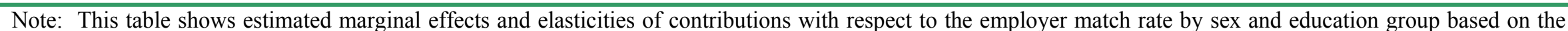

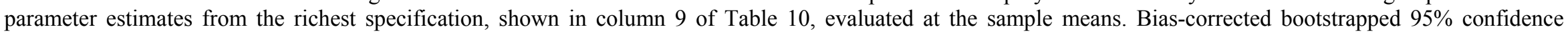
intervals are reported in square brackets.
} 


\section{Appendix Figures}

Figure 1

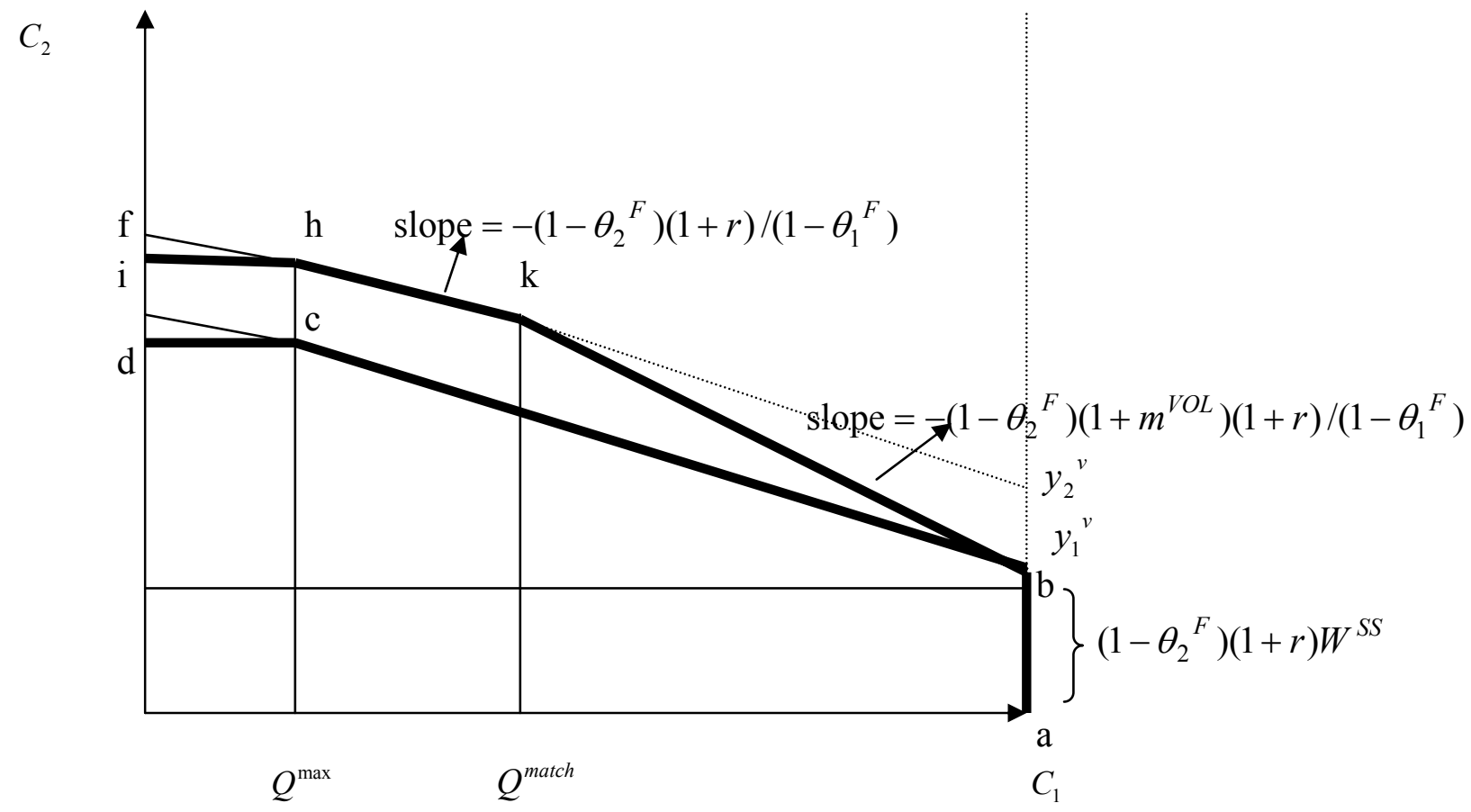


Figure 2. Marginal Tax Rates in 1989 and 1991

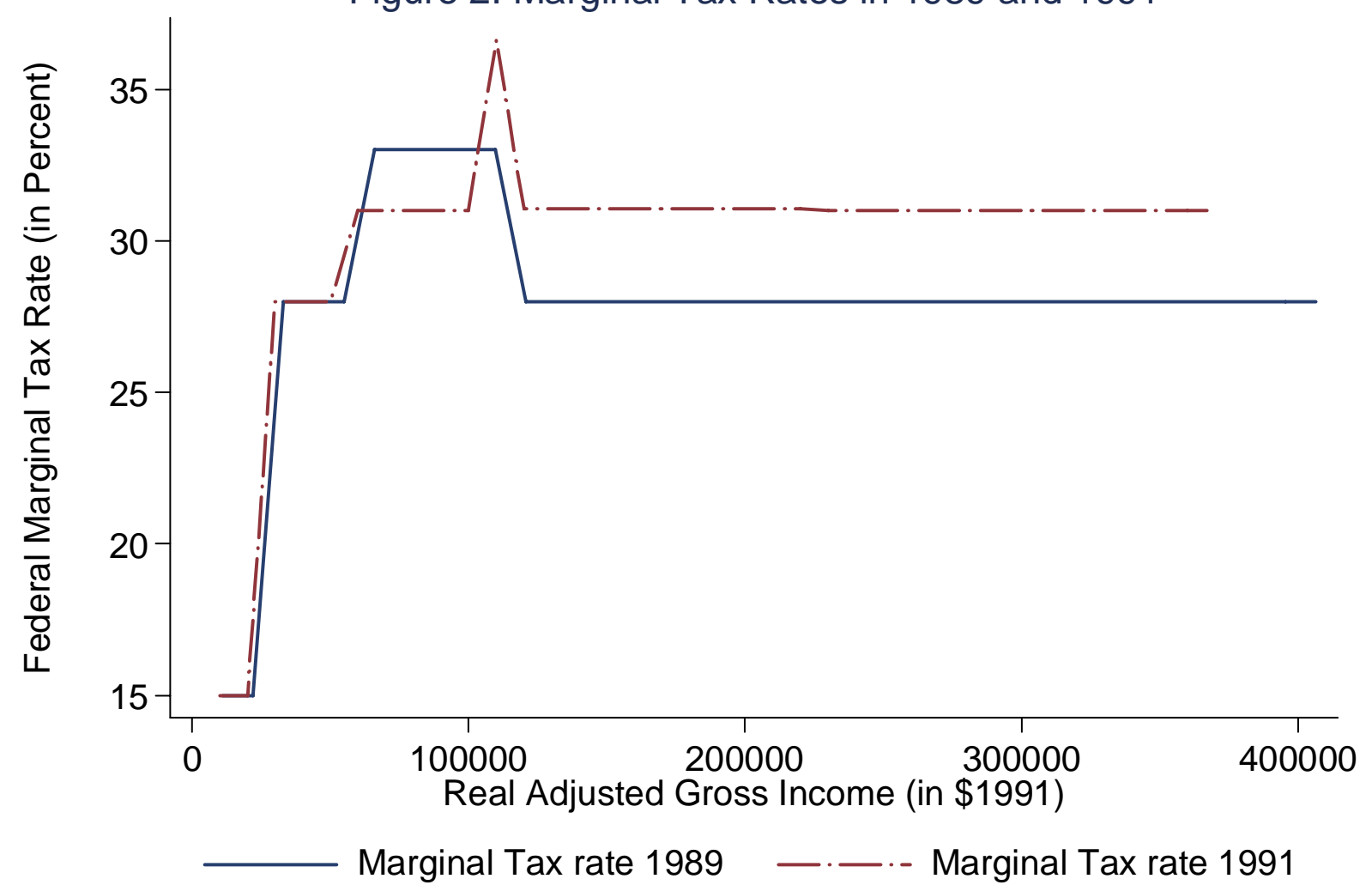

